(c) American Dairy Science Association, 2006.

\title{
Effects of Physically Effective Fiber on Digestive Processes and Milk Fat Content in Early Lactating Dairy Cows Fed Total Mixed Rations
}

\author{
Q. Zebeli, ${ }^{1}$ M. Tafaj, H. Steingass, B. Metzler, and W. Drochner \\ University of Hohenheim, Institute of Animal Nutrition (450), Emil-Wolff-Str. 10, D-70599 Stuttgart, Germany
}

\begin{abstract}
Data from recent research studies were analyzed quantitatively, and the random effect of experiment was assessed to define the physiological responses of dairy cows in early lactation to intake of physically effective neutral detergent fiber (peNDF). All studies were conducted with lactating Holstein cows (84.8 \pm 3.54 days in milk) in Latin square designs, and feeds were offered ad libitum as total mixed rations (TMR). The peNDF was estimated by 2 measurement techniques, the NDF content of TMR multiplied by amount of dry matter $(\mathrm{DM})$ retained on a $1.18-\mathrm{mm}$ screen $($ peNDF $>1.18$ ) and NDF content of TMR multiplied by the proportion of DM retained by 19- and 8-mm Penn State Particle Separator screens $\left(\mathrm{peNDF}_{>8}\right)$. Other factors, including concentrations of NDF, forage NDF, nonfiber carbohydrates, the amount of digestible organic matter of forages (FDOM), and the intake of ruminally degradable starch (RDSI) from grain in the diet were also investigated. The studied animal response variables included feed intake, ruminal fermentation, chewing activity, fiber digestibility, and milk production and composition. The ruminal $\mathrm{pH}$ (day mean) in this study ranged from 5.30 to 6.59 . Using peNDF $>1.18$ approach, the requirements for physically effective fiber in high-yielding dairy cows fed TMR in an ad libitum intake were estimated to be about $19 \%$ of ration DM or $4.1 \mathrm{~kg} / \mathrm{d}$ or $0.6 \mathrm{~kg} / 100 \mathrm{~kg}$ of body weight to maintain a ruminal $\mathrm{pH}$ of about 6.0. When peNDF was measured as peNDF $>8$, ruminal $\mathrm{pH}$ responded in a quadratic fashion but the confidence of estimation was lower $\left(\mathrm{R}^{2}=\right.$ 0.27) compared with the peNDF $>1.18$ approach $\left(\mathrm{R}^{2}=\right.$ 0.67). Results of these data analyses showed that peNDF $>1.18$ provided a satisfactory estimation of the mean ruminal $\mathrm{pH}\left(\mathrm{R}^{2}=0.67\right)$ and NDF digestibility $\left(\mathrm{R}^{2}=0.56\right)$. Furthermore, peNDF $>1.18$ was poorly, although positively, correlated to daily chewing $\left(R^{2}=\right.$ $0.17)$, and rumination $\left(\mathrm{R}^{2}=0.24\right)$ activity. On the other hand, results from these analyses showed that milk
\end{abstract}

Received June 22, 2005.

Accepted September 29, 2005.

${ }^{1}$ Corresponding author: zebeli@uni-hohenheim.de parameters are less sensitive to the effects of dietary peNDF than other variables, such as ruminal $\mathrm{pH}$, chewing activity, and fiber digestibility. Dietary FDOM correlated positively (moderately) to ruminal $\mathrm{pH}\left(\mathrm{R}^{2}=\right.$ $0.24)$, daily chewing $\left(R^{2}=0.23\right)$, and rumination $\left(R^{2}=\right.$ $0.29)$ activity, whereas the daily RDSI from grain correlated negatively to ruminal $\mathrm{pH}\left(\mathrm{R}^{2}=0.55\right)$ and positively to total volatile fatty acids $\left(R^{2}=0.27\right)$. Inclusion of FDOM and RDSI from grain along with peNDF ${ }_{>1.18}$ in the models that predict rumen $\mathrm{pH}$ further improved the accuracy of prediction. This approach appeared to further complement the concept of peNDF that does not account for differences in ruminal fermentability of feeds.

Key words: physically effective fiber, dairy cow, rumen $\mathrm{pH}$, chewing activity

\section{INTRODUCTION}

High-concentrate diets for high-yielding dairy cows must contain sufficient physically effective fiber (i.e., fiber that stimulates rumination, saliva production, and rumen buffering) to prevent ruminal dysfermentation and subacute ruminal acidosis (SARA). The concept of physically effective fiber was created to amalgamate the chemical characteristics and particle size of forages, and to quantify its value to rumen function (Mertens, 2000). According to Lammers et al. (1996), physically effective NDF (peNDF) could be measured as a proportion of DM retained by the 19- and 8-mm Penn State Particle Separator (PSPS) screens multiplied by dietary NDF content $\left(\mathbf{p e N D F}_{>\mathbf{8}}\right.$ ). Mertens (1997) determined peNDF as the proportion of DM retained by a $1.18-\mathrm{mm}$ screen multiplied by dietary NDF (peNDF $>$ 1.18) using a dry-sieving technique. It is, however, unclear which measure of peNDF provides the most accurate estimate of chewing, saliva production, and rumen buffering (Einarson et al., 2004). Although a number of recent studies have been conducted to investigate the effects of peNDF on rumen fermentation, feed intake, milk production, chewing activity, and nutrient digestibility in high-yielding, early lactation dairy cows, the results obtained from these studies are not conclusive. Differences in measurement and definition of dietary peNDF and interactions between levels 
of concentrate inclusion, forage and grain sources, and animal-response variables among studies make peNDF recommendations difficult. The NRC (2001) does not give requirements for peNDF due to lack of a standardized, validated method for measuring effective fiber in feeds and to establish requirements for effective fiber.

Part of the difficulty in assigning fiber requirements for high-yielding dairy cows related to the interpretation of response variables. Despite the fact that milk fat percentage is an easily measured parameter, low fiber in the diet can detrimentally affect animal health without significant milk fat depression (Mertens, 1997). Ruminal $\mathrm{pH}$ may be a better indication of ruminal health and optimal function, and a better basis for determining fiber requirements of dairy cows in early lactation than the maintenance of milk fat production (Allen, 1997; Mertens, 1997).

However, Beauchemin and Yang (2005) concluded that the models used to predict rumen $\mathrm{pH}$ should include both peNDF and fermentable OM intake. Because the peNDF concept relates only to the physical properties of fiber, inclusion of forage and grain fermentability characteristics in the models to predict animal response and to evaluate physical effectiveness of dairy cow diets would likely increase the estimation accuracy. Results from several studies showed that increasing the amount of digestible fiber of hay or corn silage in dairy cow diets increased digesta stratification, particle breakdown in the rumen as well as digesta turnover, forage intake, and fiber digestibility without compromising the physical effectiveness at stimulating chewing (Oba and Allen, 2000b; Tafaj et al., 2004b, 2005b). Krause et al. (2002b) found that replacing dry cracked corn with high-moisture corn in a TMR fed to dairy cows significantly reduced ruminal $\mathrm{pH}$. Furthermore, Beauchemin and Rode (1997) reported that rapidly digested starch sources such as barley grain increase the need for effective fiber, suggesting an interaction between ruminal fermentability and physical characteristics of the ration.

This quantitative study aimed to define the physiological responses of high-yielding dairy cows in early lactation to peNDF when estimated as $\mathrm{peNDF}_{>1.18}$ and peNDF $_{>8}$. Furthermore, based on the most sensitive animal response variable, an optimization of peNDF concentration in TMR fed ad libitum to this category of dairy cows was also intended. Possible interactions between dietary peNDF, NFC, the amount of digestible OM of forages (FDOM), and intake of ruminally degradable starch (RDSI) from grains composing TMR were also investigated.

\section{MATERIALS AND METHODS}

\section{Description of the Database}

To conduct this quantitative study, an independent data set with data on animal characteristics, detailed ration components, and an evaluation of physical structure of the ration was generated. The data file containing 131 treatment means was generated from 33 experiments published from 1997 to 2005 (Table 1). Animals were lactating Holstein cows $(84.8 \pm 3.54$ DIM) (mean \pm SE) weighing between 570 and $886 \mathrm{~kg}$ and producing 23.1 to $49.3 \mathrm{~kg}$ of milk/d. Feeds were offered ad libitum as TMR. The level of DMI ranged from 16.9 to $28.3 \mathrm{~kg} / \mathrm{d}$, and the percentage of forage in TMR ranged from 27 to $75 \%$ of $\mathrm{DM}(49.2 \pm 0.87 \%)$. Dietary $\mathrm{NDF}$ ranged from 18.2 to $48.1 \%$ of DM $(30.9 \pm 0.51 \%)$ and forage NDF (FNDF) ranged from 15.5 to $35.8 \%$ of DM $(21.3 \pm 0.36 \%)$. The peNDF $>1.18$ content in TMR ranged from 4.2 to $37.4 \%$ of $\mathrm{DM}(21.1 \pm 0.64 \%)$ and the content of peNDF $>8$ ranged from 2.0 to $29.5 \%$ (15.2 \pm $0.73 \%$ ). The main characteristics of the database, including animal characteristics, investigated dietary factors, and animal response variables (hereafter referred to as response variables) are listed in Table 2. The response variables included data on feed intake, ruminal fermentation, chewing activity, fiber digestibility, and milk production and composition. All experiments included in this study were conducted in Latin square design.

Ruminal fermentation was investigated based on the response of total VFA, molar proportion of individual VFA, acetate to propionate ratio, and $\mathrm{pH}$ value in the ruminal fluid. For VFA measurement through GLC, ruminal fluid was collected several times after morning feeding via cannula from the ventral sac of the rumen. Some studies measured $\mathrm{pH}$ from ruminal fluid in spot samples collected from the ventral sac of the rumen, whereas in others, ruminal $\mathrm{pH}$ was continuously measured (during $24 \mathrm{~h}$ ) using an industrial electrode placed in the ventral rumen sac. However, in all cases, the measurements of ruminal $\mathrm{pH}$ covered at least a period from 8 to 10 and, in several cases, up to $12 \mathrm{~h}$ postfeeding. In the present study, values of ruminal $\mathrm{pH}$, total and individual molar amounts of VFA, and the acetate to propionate ratio reported from studies were analyzed as treatment means.

\section{Estimation of peNDF of Diets}

As a prerequisite for inclusion in this literature study, articles were expected to give complete information on the components and chemical composition of rations, as well as on the physical evaluation of experimental diets (vertical dry-sieving technique). The peNDF ${ }_{>8}$ content of TMR was determined by multiplying the proportion of DM retained by the 19- and 8-mm screens of PSPS by dietary NDF content (DM basis; Lammers et al., 1996). 
Table 1. List of references and their reported experimental parameters ${ }^{1}$ included in the analysis

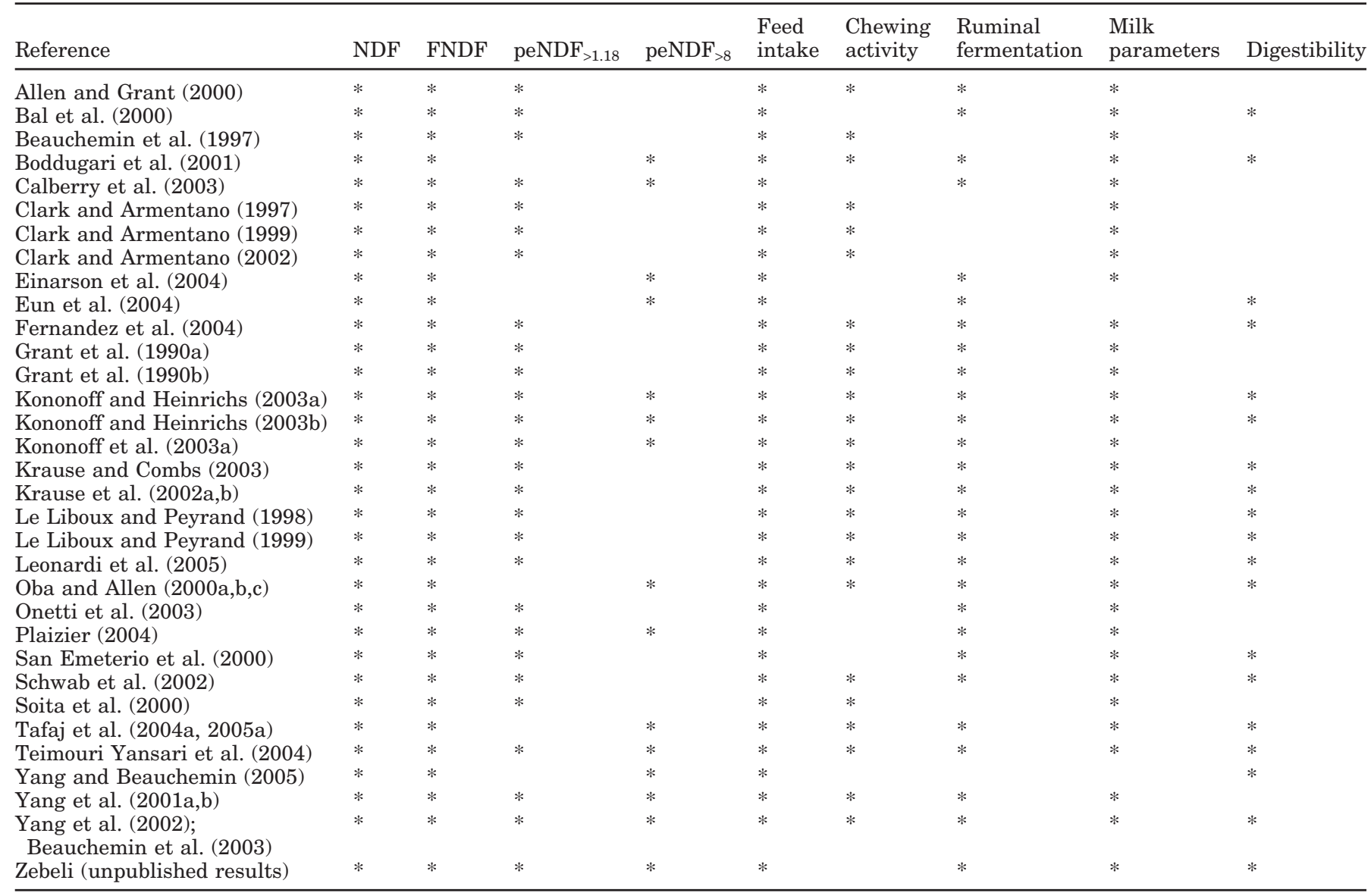

${ }^{1} \mathrm{FNDF}=$ Dietary forage NDF; peNDF $>1.18$ = dietary physically effective NDF measured as the NDF content of TMR multiplied by amount of $\mathrm{DM}_{>1.18 \mathrm{~mm}}$ (Mertens, 1997); peNDF $>8=$ Dietary physically effective NDF measured as a proportion of DM retained by 19- and 8-mm Penn State Particle Separator screens multiplied by dietary NDF content (Lammers et al., 1996).

Assuming that chewing activity is equal for all particles retained on a 1.18-mm sieve, Mertens (1997) proposed a system for estimating peNDF based on NDF concentration of feeds multiplied by the proportion of particles retained on a $1.18-\mathrm{mm}$ sieve $\left(\mathrm{peNDF}_{>1.18}\right)$ using the vertical oscillating dry-sieving technique. To estimate $\mathrm{peNDF}_{>1.18}$ content of TMR in the present study, DM proportion retained on a 1.18-mm sieve, obtained either through the vertical oscillating sieving technique or the new version of PSPS (Kononoff et al., 2003b), was multiplied by NDF content (DM basis) of TMR.

Some studies reported only the particle size distribution of their forages but not of the TMR. Grain is also reported to possess effective fiber according to its physical form (ground, pelleted, or rolled; Mertens, 1997) and degradability characteristics (De Brabander et al., 2002). To account for peNDF $>1.18$ content of concentrates in the present study, the data were used from Mertens (1997), who reported particle size distribution (propor- tion of particles retained on sieve $1.18 \mathrm{~mm}$ ) for different concentrate feeds using the vertical oscillating sieving technique. In this case, total peNDF ${ }_{>1.18}$ content of TMR was calculated as a sum of peNDF $>1.18$ obtained from forages (NDF content of forages $\times \mathrm{DM}$ retained on screens $>1.18 \mathrm{~mm}$ ) with the estimate of concentrate peNDF $_{>1.18}(\mathrm{NDF}$ content of grain $\times \mathrm{DM}$ retained on screens $>1.18 \mathrm{~mm}$, taken from tables of Mertens, 1997) according to their proportion in the TMR.

\section{Estimation of FDOM}

Nutritive value tables and chemical composition of feedstuffs from the United Kingdom (MAFF, 1990) were used to estimate the amount of FDOM for the present experimental diets. The content of FDOM was used to take into account in the analysis forage quality and the amount of fermentable OM of forages composing TMR. The United Kingdom tables express FDOM as in vitro digestible OM determined using rumen fluid-pepsin; 
Zebeli et al.

Table 2. Statistical description of animal characteristics, dietary factors, and response parameters included in the current study

\begin{tabular}{|c|c|c|c|c|c|c|c|}
\hline Parameter & $\mathrm{n}_{\text {Treat }}{ }^{1}$ & $\mathrm{n}_{\text {Ref. }}{ }^{2}$ & Mean & SE & Minimum & Maximum & Median \\
\hline \multicolumn{8}{|l|}{ Animal characteristics } \\
\hline $\mathrm{BW}, \mathrm{kg}$ & 131 & 33 & 656 & 4.36 & 570 & 886 & 656 \\
\hline DIM & 131 & 33 & 84.8 & 3.54 & 9.00 & 170 & 83.0 \\
\hline Forage in TMR, \% of DM & 131 & 33 & 49.2 & 0.87 & 26.8 & 75.0 & 50.0 \\
\hline \multicolumn{8}{|l|}{ Dietary factors, \% of DM unless stated } \\
\hline NDF & 131 & 33 & 30.9 & 0.51 & 18.2 & 48.1 & 31.6 \\
\hline $\mathrm{FNDF}^{3}$ & 131 & 33 & 21.3 & 0.46 & 11.5 & 35.8 & 21.0 \\
\hline $\operatorname{peNDF}_{>1,18 \mathrm{~mm}}{ }^{4}$ & 110 & 27 & 21.1 & 0.64 & 4.24 & 37.4 & 21.0 \\
\hline Intake of $\mathrm{peNDF}_{>1.18}, \mathrm{~kg} / \mathrm{d}$ & 110 & 27 & 4.91 & 0.16 & 0.98 & 9.97 & 4.86 \\
\hline Intake of peNDF $>1.18, \mathrm{~kg} / 100 \mathrm{~kg}$ of $\mathrm{BW}$ & 110 & 27 & 0.75 & 0.03 & 0.15 & 1.48 & 0.75 \\
\hline $\mathrm{peNDF}_{>8} 5^{5}$ & 52 & 15 & 15.2 & 0.73 & 1.98 & 29.5 & 14.8 \\
\hline Intake of $\mathrm{peNDF}_{>8}, \mathrm{~kg} / \mathrm{d}$ & 52 & 15 & 3.30 & 0.19 & 0.49 & 5.67 & 3.18 \\
\hline $\mathrm{NFC}^{6}$ & 111 & 28 & 35.8 & 0.63 & 16.5 & 53.2 & 35.5 \\
\hline NFC:NDF ratio & 111 & 28 & 1.21 & 0.03 & 0.35 & 2.89 & 1.17 \\
\hline $\mathrm{CP}$ & 131 & 33 & 17.5 & 0.14 & 12.7 & 22.1 & 17.8 \\
\hline $\mathrm{FDOM},{ }^{7} \mathrm{~g} / \mathrm{kg}$ of DM & 131 & 33 & 301 & 6.32 & 147 & 500 & 301 \\
\hline $\mathrm{RDS},{ }^{8} \mathrm{~g} / \mathrm{kg}$ of $\mathrm{DM}$ & 131 & 33 & 143 & 4.21 & 55.0 & 291 & 145 \\
\hline $\operatorname{RDSI},{ }^{9} \mathrm{~kg} / \mathrm{d}$ & 131 & 33 & 3.30 & 0.10 & 1.20 & 6.60 & 3.10 \\
\hline \multicolumn{8}{|l|}{ Response variables } \\
\hline $\mathrm{DM}$ intake, $\mathrm{kg} / \mathrm{d}$ & 131 & 33 & 23.0 & 0.17 & 16.9 & 28.3 & 22.8 \\
\hline DM intake, $\mathrm{kg} / 100 \mathrm{~kg}$ of $\mathrm{BW}$ per $\mathrm{d}$ & 131 & 33 & 3.50 & 0.03 & 2.40 & 4.50 & 3.50 \\
\hline Ruminal pH (day mean) & 100 & 26 & 6.09 & 0.02 & 5.30 & 6.59 & 6.09 \\
\hline \multicolumn{8}{|l|}{ VFA } \\
\hline Total VFA, mM/L mol/100 mol VFA & 100 & 26 & 114 & 2.08 & 75.0 & 162 & 111 \\
\hline Acetate $\left(\mathrm{C}_{2}\right)$ & 100 & 26 & 58.6 & 0.56 & 44.6 & 73.6 & 59.4 \\
\hline Propionate $\left(\mathrm{C}_{3}\right)$ & 100 & 26 & 22.9 & 0.50 & 10.7 & 35.9 & 22.9 \\
\hline Butyrate $\left(\mathrm{C}_{4}\right)$ & 100 & 26 & 12.7 & 0.20 & 8.9 & 18.1 & 12.2 \\
\hline Acetate-to-propionate ratio & 100 & 26 & 2.66 & 0.06 & 1.34 & 5.05 & 2.60 \\
\hline \multicolumn{8}{|l|}{ Total chewing time } \\
\hline $\mathrm{Min} / \mathrm{d}$ & 99 & 24 & 691 & 11.2 & 425 & 969 & 702 \\
\hline Min/kg of DM & 99 & 24 & 30.1 & 0.59 & 17.9 & 47.1 & 29.7 \\
\hline $\mathrm{Min} / \mathrm{kg}$ of $\mathrm{NDF}$ & 99 & 24 & 103 & 2.48 & 54.3 & 160 & 101 \\
\hline $\mathrm{Min} / \mathrm{kg}$ of $\mathrm{peNDF}_{>1.18}$ & 87 & 21 & 167 & 9.67 & 70.5 & 644 & 143 \\
\hline Rumination time, $\mathrm{min} / \mathrm{d}$ & 99 & 24 & 434 & 8.29 & 151 & 632 & 443 \\
\hline Milk yield, kg/d & 131 & 33 & 34.9 & 0.51 & 23.1 & 49.3 & 34.8 \\
\hline Milk fat, \% & 131 & 33 & 3.40 & 0.03 & 2.39 & 4.23 & 3.43 \\
\hline Milk protein, \% & 121 & 32 & 3.11 & 0.01 & 2.63 & 3.76 & 3.14 \\
\hline Fat:protein ratio in milk & 121 & 32 & 1.09 & 0.01 & 0.75 & 1.42 & 1.12 \\
\hline \multicolumn{8}{|l|}{ Digestibility, \% } \\
\hline NDF & 73 & 19 & 46.9 & 0.96 & 28.4 & 64.6 & 47.2 \\
\hline $\mathrm{ADF}$ & 56 & 15 & 43.8 & 1.09 & 22.0 & 58.9 & 44.6 \\
\hline
\end{tabular}

${ }^{1}$ Number of treatment means.

${ }^{2}$ Number of experiments included in this study.

${ }^{3} \mathrm{FNDF}=$ Dietary forage NDF.

${ }^{4}$ Physically effective NDF measured as the NDF content of TMR multiplied by amount of $\mathrm{DM}_{>1.18-\mathrm{mm}}$ (Mertens, 1997).

${ }^{5}$ Physically effective NDF measured as the NDF content of TMR multiplied by amount of $\mathrm{DM}_{>} 8-\mathrm{mm}$ (Lammers et al., 1996)

${ }^{6}$ Nonfiber carbohydrate calculated by difference $100-(\% \mathrm{CP}+\% \mathrm{NDF}+\%$ ether extract $+\%$ crude ash $)$. ${ }^{7} \mathrm{FDOM}=$ Amount of digestible OM of forages in TMR estimated by MAFF (1990).

${ }^{8} \mathrm{RDS}=$ Ruminally degradable starch from grain in TMR calculated according to Offner et al. (2003).

${ }^{9} \mathrm{RDSI}=$ Daily intake of RDS.

for forages constituting diets of this study was set as follows (in $\mathrm{g} / \mathrm{kg}$ of $\mathrm{DM}$ ): corn silage (667), alfalfa hay (557), alfalfa silage (547), barley silage (684), mixed grass silage (587), oat silage (684), grass hay (suncured) (564). Furthermore, the total amount of dietary FDOM content was calculated based on the proportion of forages in the experimental TMR.

\section{Estimation of Ruminally Degradable Starch of Grain}

All published studies analyzed provided sufficient information about the components of concentrate mixture of their TMR. To account for differences of ruminal degradability characteristics among grains comprising experimental TMR in the present study, the in situ 
effective ruminal degradability of starch from grain was taken into consideration. Starch content of grain in TMR was either taken directly from articles or was taken from tables compiled by Sauvant et al. (2004). The amount of ruminally degradable starch (RDS; \% of total starch) of grain mixture composing TMR was calculated according to the formula: $\mathrm{RDS}=\Sigma \mathrm{p} i \times \mathrm{ERD} i$, where pi represents the proportion of dietary starch provided from grain $i$ in the mixture, and $\mathrm{ERD}_{\mathrm{i}}$ represents starch effective degradability for grain $i$, which was taken from in situ calculations made from Offner et al. (2003) for a fractional passage rate of $6 \% / \mathrm{h}$. To take into account the RDSI from grain in the analysis, RDSI was calculated by multiplying the daily DM intake with RDS of grain comprising TMR. A statistical description of the calculated in situ RDS and RDSI from grain of this study, including mean, range, and median, is given in Table 2 .

\section{Statistical Analyses}

Data analysis was performed according to St-Pierre (2001) taking into account the random effect of the experiment, using PROC MIXED (version 8.2, SAS Institute, 2001). The variable experiment (hereafter referred as study) does not contain quantitative information and constitutes an additional variation source; it was therefore declared in the CLASS statement. Simple linear regression was performed to test the response of animal variables to dietary factors (refer to Table 2 for information regarding response variables and dietary factors). Therefore, dependent variables in the regression analysis included all response variables and the independent continuous variables included all dietary factors according to the following model:

$$
\mathrm{Y}_{i j}=\alpha_{0}+\mathrm{s}_{i}+\beta_{1} \mathrm{X}_{i j}+\mathrm{b}_{i} \mathrm{X}_{i j}+\mathrm{e}_{i j},
$$

where Yij = the expected outcome for the dependent variable $\mathrm{Y}$ (response variable) observed at level $j$ of the continuous variable $\mathrm{X}$ (dietary factor) in the study $i$, $\alpha_{0}=$ the overall intercept across all studies (fixed effect), $\mathrm{s}_{\mathrm{i}}=$ the random effect of the study $i(i=1, \ldots, 33), \beta_{1}=$ the overall regressing coefficient of $\mathrm{Y}$ on $\mathrm{X}$ across all studies (fixed effect), $\mathrm{X}_{\mathrm{ij}}=$ the value $j$ of continuous variable $\mathrm{X}$ in study $i, \mathrm{~b} i=$ the random effect of study $i$ on the regression coefficient of $\mathrm{Y}$ on $\mathrm{X}$ in study $i$, and eij $=$ the unexplained error.

To take into consideration the unequal variance among studies, all dependent variables were weighted by the reciprocal of their squared standard error. In addition, an unstructured variance-covariance matrix (type $=$ un) was performed at the random part of the model, as suggested by St-Pierre (2001) to avoid the positive correlation between the intercepts and slopes. When dietary factors were $P<0.05$, their squared term was included in the model to test any likely quadratic relationship (second-order polynomial regression) and a variance components (type $=\mathrm{vc}$ ) of variance-covariance structure was performed to avoid the positive correlation between the intercepts and slopes (St-Pierre, 2001). To fit the asymptotic relationship of ruminal $\mathrm{pH}$ or chewing index to dietary $\mathrm{pNDF}_{>1.18}$, a mathematical asymptotic function using PROC NLIN (DUD method; SAS Inst. Inc., version 8.2) according to the following model was used:

$$
\mathrm{Y}=\mathrm{a}+\mathrm{b} \mathrm{e}^{(\mathrm{cX})}
$$

where Y represents the response variable; $a, b$, and c are the estimates, and $\mathrm{X}$ represents the dietary peNDF $>1.18$.

All significant dietary factors $(P<0.05)$ were further tested using the backward elimination multiple regression similarly to the algorithm reported by Oldick et al. (1999) and Firkins et al. (2001). To limit overparameterization of the model, a variance inflation factor less than 10 for every continuous independent variable tested was assumed, as suggested by Oldick et al. (1999). The best fit was chosen as the one with the lowest root mean square error (RMSE), higher determination coefficient $\left(R^{2}\right)$, and the highest Schwarz's Bayesian criterion. For simplicity, only the best-fit equations of multiple regression (backward elimination) that further improved the relationship obtained from linear or polynomial regression are shown.

\section{RESULTS AND DISCUSSION}

\section{Intakes of DM and peNDF}

A summary of intakes for diets used in this quantitative study is given in Table 2. Intake of DM from 33 studies averaged $23.0 \pm 0.17 \mathrm{~kg} / \mathrm{d}$ or $3.5 \pm 0.03 \mathrm{~kg} / 100$ $\mathrm{kg}$ of BW per d. Intakes of peNDF $>1.18$ from 27 studies and $\mathrm{peNDF}_{>8}$ from 15 studies averaged $4.9 \pm 0.16 \mathrm{~kg} / \mathrm{d}$ and $3.3 \pm 0.19 \mathrm{~kg} / \mathrm{d}$, respectively. Table 3 shows the results of linear regression of DMI response to different dietary factors (for simplicity, only significant relationships are shown, $P<0.05$ ). The analysis of backward elimination of multiple regression did not further improve the relationship obtained from linear regression, and therefore, the results are not shown. In general, relationships of dietary factors to DMI were low in this study. The dietary NDF negatively affected DMI (expressed as either $\mathrm{kg} / \mathrm{d}$ or $\mathrm{kg}$ of $\mathrm{DM} / 100 \mathrm{~kg}$ of BW per d), although the relationship was moderately higher when peNDF was measured as peNDF $>1.18\left(\mathrm{R}^{2}=0.21\right)$ and when BW of animals was included in the analysis 
Table 3. Equations ${ }^{1}$ for linear and polynomial regression of response of DMI (Y, kg/d or kg/100 kg of BW per d) to different dietary factors in dairy cows fed TMR

\begin{tabular}{|c|c|c|c|c|c|c|c|}
\hline \multirow[b]{2}{*}{ DMI (Y) } & \multirow[b]{2}{*}{ Dietary factor $^{2}(\mathrm{X})$} & \multicolumn{4}{|c|}{ Parameter estimates } & \multicolumn{2}{|c|}{ Model statistics } \\
\hline & & Intercept & $\mathrm{SE}_{\text {Intercept }}$ & Slope & $\mathrm{SE}_{\text {Slope }}$ & $\mathrm{RMSE}^{3}$ & $\mathrm{R}^{2}$ \\
\hline \multirow[t]{4}{*}{$\mathrm{kg} / \mathrm{d}$} & $\begin{array}{l}\text { peNDF }_{>1.18}, \% \\
\text { peNDF }^{2}>1.18, \%\end{array}$ & 24.6 & 0.87 & $\begin{array}{r}-0.261 \\
0.008\end{array}$ & $\begin{array}{l}0.084 \\
0.002\end{array}$ & 1.38 & 0.21 \\
\hline & NFC:NDF ratio & 18.4 & 1.05 & 6.319 & 1.529 & 1.71 & 0.16 \\
\hline & NDF, \% & 26.7 & 0.73 & -0.120 & 0.023 & 1.56 & 0.17 \\
\hline & FNDF, \% & 25.4 & 0.60 & -0.113 & 0.027 & 1.65 & 0.12 \\
\hline \multirow{2}{*}{$\mathrm{kg} / 100 \mathrm{~kg}$ of $\mathrm{BW}$ per $\mathrm{d}$} & peNDF $_{>118}, \%$ & 4.21 & 0.10 & -0.034 & 0.005 & 0.28 & 0.29 \\
\hline & $\mathrm{NDF}, \%$ & 4.33 & 0.13 & -0.027 & 0.004 & 0.29 & 0.23 \\
\hline
\end{tabular}

${ }^{1}$ Only significant relationships are shown $(P<0.05)$.

${ }^{2} \mathrm{peNDF}_{>1.18}=$ Physically effective NDF measured as the NDF content of TMR multiplied by amount of $\mathrm{DM}_{>1.18-\mathrm{mm}}($ Mertens, 1997$) ; \mathrm{NFC}=$ Nonfiber carbohydrate calculated by difference $100-(\% \mathrm{CP}+\% \mathrm{NDF}$ $+\%$ ether extract $+\%$ crude ash); FNDF $=$ Forage NDF.

${ }^{3} \mathrm{RMSE}=$ Root mean square error.

$\left(\mathrm{R}^{2}=0.29\right)$. Dry matter intake also responded positively to NFC:NDF ratio of the diet. These responses are presumably connected with the ruminal physical fill effect of NDF and the high energetic necessity of dairy cows in early lactation. Cows in early lactation are often in negative energy balance because the ingested energy does not meet the energy requirements of lactation (NRC, 2001). The extent to which DMI of lactating dairy cows is regulated by distension in the reticulorumen depends upon the animal's energy requirement and the filling effect of the diet offered (Allen, 2000). However, Allen (2000) stated that physical fill could limit feed intake at the low concentrate inclusion, but a metabolic rather than a physical constraint can be expected to be rate limiting at high concentrate inclusion. Beauchemin et al. (1994) reported an interaction $(P<0.01)$ between forage particle length (alfalfa silage chopped at 5 - and $10-\mathrm{mm}$ theoretical length of cut) and percentage of forage in the diet ( 35 or $65 \%$ ). In that experiment, DMI was reduced by nearly $3 \mathrm{~kg} / \mathrm{d}$ when forage percentage was increased from 35 to 65 with diets containing the long-chopped alfalfa silage, but was reduced by less than $0.5 \mathrm{~kg} / \mathrm{d}$ with diets containing shortchopped silage. Tafaj et al. (2001) reported that reducing dietary hay particle size from 28.7 to $9.2 \mathrm{~mm}$ increased DMI by $13 \%$ only at a low-concentrate level (13\% in DM), but when a high-concentrate $\operatorname{diet}(\sim 40 \%$ in DM) was fed no differences were observed in sheep. Firkins et al. (2001) quantitatively analyzed results from literature in dairy cows with a comparable DMI to the present study $(21.3 \pm 2.6 \mathrm{~kg} / \mathrm{d})$ and reported a negative linear relationship among dietary NDF and FNDF and DMI. Recently, Beauchemin and Yang (2005) reported that reducing dietary $\mathrm{peNDF}_{>8}$ from 11.5 to $8.9 \%$ ration DM was not a rate-limiting step for particulate passage and hence, for rumen physical fill and feed intake in Holstein cows fed corn silage-based TMR with a high concentrate level ( $60 \%$ of ration DM).

\section{Ruminal Fermentation}

In this study, ruminal $\mathrm{pH}$ (day mean) ranged from 5.30 to $6.59(6.09 \pm 0.02)$ whereas total VFA and acetate to propionate ratio ranged from 75 to $162 \mathrm{mM} / \mathrm{L}$ and from 1.34 to 5.05, respectively. Acute acidosis is defined as a condition in which ruminal $\mathrm{pH}$ is less than approximately 5.0 to 5.2 , whereas SARA is defined as a ruminal $\mathrm{pH}$ of approximately 5.2 to 5.6 (Owens et al., 1998). Garrett et al. (1999) proposed that a group of cows would be characterized (presence or absence of SARA) correctly $90 \%$ of the time if 3 or more of 12 tested cows had readings $\leq 5.5$, whereas Beauchemin et al. (2003) stated that the incidence of subclinical acidosis increases when ruminal $\mathrm{pH}$ falls below 5.8. Of 100 treatment means used in the present study, ruminal $\mathrm{pH}$ was $\leq 5.8$ in 11 cases (results not shown). Table 2 shows a summary of all parameters of ruminal fermentation analyzed in this study. The regression analysis showed that ruminal $\mathrm{pH}$ responded quadratically to $\operatorname{peNDF}_{>1.18}$ of the diet (Figure 1). When peNDF was measured as the proportion of particles retained on the 8-mm screen $\left(\mathrm{peNDF}_{>8}\right)$, the relationship was also quadratic but the confidence of estimation was lower (Table 4). The maximal amount of peNDF $>8$ intake associated with the quadratic effect resulted to be about 4.5 $\mathrm{kg} / \mathrm{d}$ (data not shown).

Table 4 shows the results of linear regression of response of fermentation parameters ( $\mathrm{pH}$, total VFA, acetate to propionate ratio, and butyrate molar percentage) to different dietary factors (only significant relationships are shown, $P<0.05$ ).

According to Figure 1, peNDF $>1.18$ estimates ruminal $\mathrm{pH}$ with $\mathrm{R}^{2}=0.67$ and an RMSE of $0.137 \mathrm{pH}$ units. Increasing the dietary peNDF increased the ruminal $\mathrm{pH}$ quadratically. The same relationship was found when peNDF $>1.18$ was expressed as intake $(\mathrm{kg} / \mathrm{d})$ or intake per $\mathrm{kg}$ of $\mathrm{BW}(\mathrm{kg} / 100 \mathrm{~kg}$ of $\mathrm{BW})$. It means that 


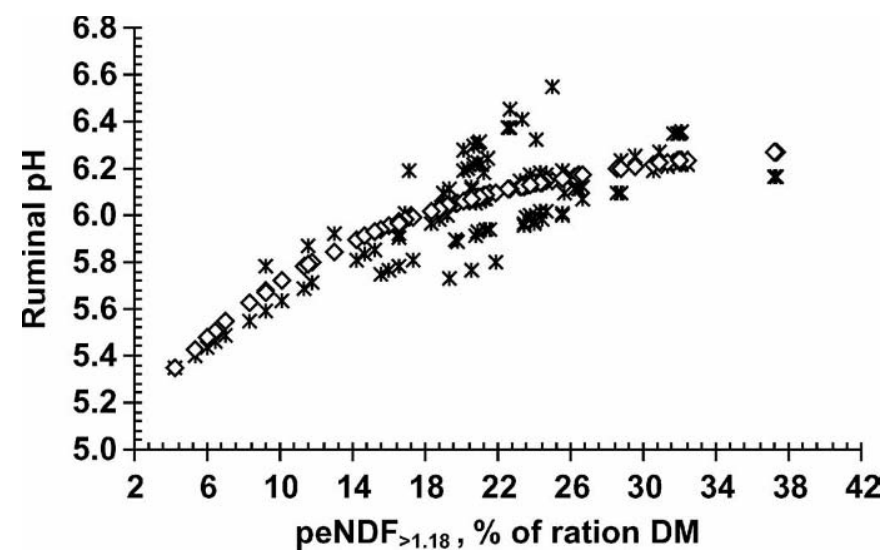

Figure 1. Relationship of physically effective NDF $\left(\operatorname{peNDF}_{>1.18}\right)$ to observed ruminal $\mathrm{pH}$ value adjusted for the random study effect and unequal variance. The best-fit, quadratic regression $\mathrm{pH}=5.06$ $( \pm 0.09)+0.069( \pm 0.008) \mathrm{peNDF}_{>1.18}-0.001( \pm 0.0002) \mathrm{peNDF}^{2}>1.18$, root mean square error $=0.137, R^{2}=0.67$; Asymptotic function $(\diamond)$ $\mathrm{pH}=6.34-1.39 \mathrm{e}^{(-0.08}$ peNDF>1.18) $u$ using Proc NLIN (SAS Institute, 2001).

with increasing dietary peNDF $>1.18$, ruminal $\mathrm{pH}$ does not increase indefinitely, but rather attains an asymptotic plateau in response to dietary peNDF $>1$ 18. Allen (1997) stated that roughages have a critical particle length and any increase thereafter does not further improve their physical effectiveness. However, in this study, the relationship between ruminal $\mathrm{pH}$ and dietary peNDF $_{>1.18}$ appeared to follow a quasi-linear course up to a $\mathrm{pH}$ value of approximately 6.0. Subsequently, the mathematical asymptotic function revealed an asymptotic relationship of ruminal $\mathrm{pH}$ with dietary peNDF $>1.18$, showing an approximated plateau at a ruminal $\mathrm{pH}$ of 6.2 and in response to about $30 \%$ dietary peNDF $_{>1.18}$ (Figure 1). Pitt et al. (1996) calculated ruminal $\mathrm{pH}$ from the equilibrium between ruminal acidity and buffering. In fact, they postulated that the crossover point representing acid-base equilibrium and the predicted steady state ruminal $\mathrm{pH}$ resulted at a ruminal $\mathrm{pH}$ of about 6.1. Mertens (1997) also reported a quadratic relationship between dietary peNDF $>1.18$ and ruminal $\mathrm{pH}\left(\mathrm{R}^{2}=0.71\right)$. Pitt et al. (1996) used data from sheep, beef cattle, and dairy cattle and observed a quadratic relationship between effective NDF and ruminal $\mathrm{pH}\left(\mathrm{R}^{2}=0.52\right)$. In the study of Pitt et al. (1996), the sheep consumed a high-forage diet, which probably accounted for a higher plateau of ruminal $\mathrm{pH}$ in that study ( 6.4).

Furthermore, our analysis also shows that dietary NDF, FNDF, and FDOM positively influenced ruminal $\mathrm{pH}$, whereas both the NFC:NDF ratio and RDSI from grain indicated a linear negative effect (Table 4). This result is partly in accordance with Allen (1997), who found a positive correlation only between FNDF and

Table 4. Equations ${ }^{1}$ for linear and polynomial regression of response of rumen fermentation parameters to different dietary factors in dairy cows fed TMR

\begin{tabular}{|c|c|c|c|c|c|c|c|}
\hline \multirow{2}{*}{$\begin{array}{l}\text { Rumen parameters } \\
\text { (Y) }\end{array}$} & \multirow{2}{*}{$\begin{array}{l}\text { Dietary factor }{ }^{2} \\
\text { (X) }\end{array}$} & \multicolumn{4}{|c|}{ Parameter estimates } & \multicolumn{2}{|c|}{ Model statistics } \\
\hline & & Intercept & $\mathrm{SE}_{\text {Intercept }}$ & Slope & $\mathrm{SE}_{\text {Slope }}$ & $\mathrm{RMSE}^{3}$ & $\mathrm{R}^{2}$ \\
\hline \multirow[t]{6}{*}{ Rumen $\mathrm{pH}$} & $\begin{array}{l}\text { peNDFI }_{>8}, \mathrm{~kg} / \mathrm{d} \\
\text { peNDFI }^{2}, \mathrm{~kg} / \mathrm{d}\end{array}$ & 5.79 & 0.05 & $\begin{array}{r}0.180 \\
-0.021\end{array}$ & $\begin{array}{l}0.039 \\
0.006\end{array}$ & 0.14 & 0.27 \\
\hline & $\mathrm{NDF}, \%$ & 5.46 & 0.07 & 0.019 & 0.002 & 0.13 & 0.44 \\
\hline & FNDF, \% & 5.70 & 0.05 & 0.017 & 0.002 & 0.13 & 0.32 \\
\hline & NFC:NDF & 6.34 & 0.05 & -0.208 & 0.038 & 0.16 & 0.23 \\
\hline & FDOM, g/kg DM & 5.76 & 0.06 & 0.001 & 0.0001 & 0.14 & 0.24 \\
\hline & RDSI, $\mathrm{kg} / \mathrm{d}$ & 6.47 & 0.03 & -0.114 & 0.009 & 0.11 & 0.55 \\
\hline \multirow[t]{6}{*}{ VFA, $\mathrm{m} M / \mathrm{L}$} & $\operatorname{peNDF}_{>118}, \%$ & 137 & 5.47 & -0.915 & 0.247 & 16.7 & 0.12 \\
\hline & peNDFI $_{>8}, \%$ & 131 & 2.99 & -1.491 & 0.233 & 15.5 & 0.25 \\
\hline & NDF, $\%$ & 161 & 7.24 & -1.506 & 0.230 & 15.4 & 0.25 \\
\hline & FNDF, \% & 145 & 5.68 & -1.497 & 0.258 & 15.6 & 0.22 \\
\hline & NFC:NDF & 91.3 & 5.11 & 4.015 & 6.497 & 16.8 & 0.19 \\
\hline & RDSI, $\mathrm{kg} / \mathrm{d}$ & 86.1 & 4.16 & 0.19 & 0.027 & 14.9 & 0.27 \\
\hline \multirow{2}{*}{$\mathrm{C}_{2}: \mathrm{C}_{3}$ ratio } & $\mathrm{NDF}, \%$ & 1.54 & 0.24 & 0.034 & 0.007 & 0.51 & 0.13 \\
\hline & NFC:NDF & 3.16 & 0.17 & -0.481 & 0.134 & 0.56 & 0.11 \\
\hline \multirow[t]{2}{*}{$\mathrm{C}_{4}, \mathrm{~mol} / 100 \mathrm{~mol}$ of VFA } & FNDF, $\%$ & 9.72 & 0.60 & 0.135 & 0.027 & 1.49 & 0.19 \\
\hline & NFC, \% & 16.7 & 0.92 & -0.119 & 0.024 & 1.40 & 0.22 \\
\hline
\end{tabular}

${ }^{1}$ Only significant relationships are shown $(P<0.05)$.

${ }^{2}$ peNDFI $_{>8}=$ Physically effective NDF measured as the NDF content of TMR multiplied by amount of $\mathrm{DM}_{>8-\mathrm{mm}}$ (Lammers et al., 1996); FNDF = forage NDF; FDOM = amount of digestible OM of forages in TMR estimated by MAFF (1990); peNDF $_{>1.18}=$ physically effective NDF measured as the NDF content of TMR multiplied by amount of $\mathrm{DM}_{>1.18-\mathrm{mm}}$ (Mertens, 1997); $\mathrm{NFC}=$ nonfiber carbohydrate calculated by difference $100-(\% \mathrm{CP}+\% \mathrm{NDF}+\%$ ether extract $+\%$ crude ash $) ; \mathrm{RDSI}=$ intake of ruminally degradable starch from grain.

${ }^{2} \mathrm{RMSE}=$ Root mean square error. 
Table 5. Estimating the physically effective $\mathrm{NDF}\left(\mathrm{peNDF}_{>1.18}{ }^{1}\right)$ required to maintain a specified ruminal $\mathrm{pH}$ of cows in early lactation fed TMR

\begin{tabular}{llcc}
\hline & \multicolumn{3}{c}{ Rumen $\mathrm{pH}$ regressed on peNDF $>1.18$} \\
\cline { 2 - 4 } & $\mathrm{kg} / 100 \mathrm{~kg}$ of BW & $\mathrm{kg} / \mathrm{d}$ & $\begin{array}{c}\text { \% of ration } \\
\mathrm{DM}\end{array}$ \\
\hline Polynomial regression & & & \\
Rumen pH intercept of all experiments & $5.40(0.08)^{2}$ & $5.18(0.07)$ & $5.07(0.09)$ \\
Linear regression coefficient & $1.31(0.21)$ & $0.27(0.03)$ & $0.069(0.008)$ \\
Quadratic regression coefficient & $-0.54(0.13)$ & $-0.017(0.002)$ & $-0.001(0.0002)$ \\
Root mean square error (RMSE) & 0.144 & 0.127 & 0.137 \\
$\mathrm{R}^{2}$ & 0.60 & 0.66 & 0.67 \\
peNDF & & & \\
5.8 & $0.35(0.01)$ & $2.8(0.07)$ & $13(0.15)$ \\
5.9 & $0.47(0.01)$ & $3.4(0.08)$ & $16(0.15)$ \\
6.0 & $0.58(0.01)$ & $4.1(0.08)$ & $19(0.17)$ \\
6.1 & $0.80(0.02)$ & $5.1(0.10)$ & $23(0.20)$ \\
\hline
\end{tabular}

${ }^{1}$ peNDF $_{>1.18}=$ Physically effective NDF measured as the NDF content of TMR multiplied by amount of $\mathrm{DM}_{>1.18-\mathrm{mm}}$ (Mertens, 1997).

${ }^{2}$ Numbers in parentheses are standard errors of the estimates.

ruminal $\mathrm{pH}\left(\mathrm{R}^{2}=0.63\right)$ and not between total dietary NDF and pH. Firkins et al. (2001) also reported that ruminal $\mathrm{pH}$ in dairy cows correlated positively to FNDF and negatively to nonstructural carbohydrates in the ration. The estimated RDSI from grain in this study represents both the amount of ruminally degradable starch from grain and DMI. Firkins et al. (2001) found that an increase in DMI would still result in an increase in ruminally degradable starch, despite a reduction in the percentage of ruminally degraded starch caused by the increase of passage rate. In this context, Stone (2004) stated that high-producing cows might have an increased risk of SARA simply due to higher DMI. As expected in the present study, RDSI from grain correlated negatively to daily ruminal $\mathrm{pH}$, explaining $55 \%$ of its variation (Table 4). This study shows that the intake of rapidly fermentable carbohydrates is more important than total NFC percentage of the diet to be taken into account in terms of avoiding SARA in highyielding dairy cows.

Using the inverse regression, Mertens (1997) reported that a peNDF intake of $4.4 \mathrm{~kg} / \mathrm{d}$ or a concentration of $22.3 \%$ of ration $\mathrm{DM}$ is needed to maintain a mean $\mathrm{pH}$ of 6.0. According to the results of our analysis, an intake of peNDF $>1.18$ of either $4.1 \mathrm{~kg} / \mathrm{d}$, or of $0.58 \mathrm{~kg} /$ $100 \mathrm{~kg}$ of BW, or a concentration of $\sim 19 \%$ of ration DM is needed to maintain a $\mathrm{pH}$ of 6.0 (Table 5).

Although in the present study, the required concentration of $\mathrm{peNDF}_{>1.18}$ to maintain a ruminal $\mathrm{pH}$ of 6.0 is lower ( 19 vs. $22.3 \%$ of ration $\mathrm{DM}$ ), the absolute intake of peNDF $>1.18(4.1 \mathrm{~kg}$ of peNDF $>1.18$ d $)$ is much closer to the estimation of Mertens (1997; $4.4 \mathrm{~kg}$ of peNDF/d). It is noteworthy that in the study of Mertens (1997), dietary peNDF ranged between 12 and $57 \%$ of DM, whereas in this study, peNDF $>1.18$ ranged from 4.2 to
$37.4 \%$ of ration DM. Moreover, the benchmark of ruminal $\mathrm{pH}$ was $\sim 5.65$ in the study of Mertens (1997), whereas in the present study, it was 5.30 . This suggests the presence of different dietary conditions in these 2 studies, particularly with respect to TMR feeding and high-yielding dairy cows. This was also reflected by a higher asymptotic plateau of ruminal $\mathrm{pH}$ (about 6.5) found by Mertens (1997). The methodology reported by Mertens (1997) for measuring ruminal $\mathrm{pH}$ does not vary substantially ( $\mathrm{pH}$ was measured during at least an 8$\mathrm{h}$ period after feeding) from that used in the present study. Therefore, dietary differences could be attributed to discrepancies between estimations in the absolute peNDF intake and peNDF concentration to maintain a specified ruminal $\mathrm{pH}$ in the study of Mertens (1997) and this study. Allen (1995) suggested that NDF requirements could vary by \pm 5 units around a mean of $30 \%$ of ration DM, whereas Mertens (1997) suggested that the peNDF amount needed to maintain a ruminal $\mathrm{pH}$ of 6.0 should be arranged \pm 1.0 to 2.0 units. A similar approach may be needed for the estimation of $\mathrm{peNDF}_{>1.18}$, in the present study (see Table 5).

The results of analysis of multiple regression using the backward elimination procedure, where all significant dietary factors were included, are shown in Table 6. To avoid overparameterization of the model, FDOM and RDSI were separately analyzed. This analysis showed that dietary peNDF $>1.18$ (quadratically) and FDOM (linearly) significantly affected $(P<0.05)$ ruminal $\mathrm{pH}$. The same effect on ruminal $\mathrm{pH}$ was observed when RDSI along with peNDF $>1.18$ was tested in the multiple backward elimination regression, only that RDSI negatively correlated to ruminal $\mathrm{pH}$. In fact, the concept of peNDF does not account for differences in fermentability of feeds. The FDOM (expressed as g/ 
Table 6. Best-fit equations for multiple regression ${ }^{1}$ of responses of rumen fermentation parameters to different dietary factors in dairy cows fed TMR

\begin{tabular}{|c|c|c|c|c|c|c|c|}
\hline \multirow{2}{*}{$\begin{array}{l}\text { Rumen parameters } \\
\text { (Y) }\end{array}$} & \multirow{2}{*}{$\begin{array}{l}\text { Dietary factor }{ }^{2} \\
\text { (X) }\end{array}$} & \multicolumn{4}{|c|}{ Parameter estimates } & \multicolumn{2}{|c|}{ Model statistics } \\
\hline & & Intercept & $\mathrm{SE}_{\text {Intercept }}$ & Slope & $\mathrm{SE}_{\text {Slope }}$ & $\mathrm{RMSE}^{3}$ & $\mathrm{R}^{2}$ \\
\hline \multicolumn{8}{|l|}{ Rumen $\mathrm{pH}^{4}$} \\
\hline Model 1 & $\begin{array}{l}\text { peNDF }_{>1.18}, \% \\
\text { peNDF }^{2}>1.18, \% \\
\text { FDOM, } / \mathrm{kg} \text { of DM }\end{array}$ & 4.87 & 0.10 & $\begin{array}{r}0.065 \\
-0.001 \\
0.001\end{array}$ & $\begin{array}{l}0.009 \\
0.0002 \\
0.0001\end{array}$ & 0.12 & 0.72 \\
\hline Model 2 & $\begin{array}{l}\text { peNDF }_{>1.18}, \% \\
\text { peNDF } \\
\text { RDSI, kg/d }\end{array}$ & 5.43 & 0.08 & $\begin{array}{r}0.076 \\
-0.001 \\
-0.092\end{array}$ & $\begin{array}{l}0.007 \\
0.0001 \\
0.011\end{array}$ & 0.12 & 0.75 \\
\hline VFA, mM/L & $\begin{array}{l}\text { peNDF }_{>8} \% \\
\text { NFC:NDF }\end{array}$ & 127 & 9.30 & $\begin{array}{l}-1.995 \\
12.133\end{array}$ & $\begin{array}{l}0.312 \\
5.876\end{array}$ & 15.3 & 0.47 \\
\hline $\mathrm{C}_{4}, \mathrm{~mol} / 100 \mathrm{~mol}$ of VFA & $\begin{array}{l}\text { FNDF, \% } \\
\text { NFC, \% }\end{array}$ & 11.5 & 1.05 & $\begin{array}{r}0.139 \\
-0.055\end{array}$ & $\begin{array}{l}0.025 \\
0.020\end{array}$ & 1.34 & 0.33 \\
\hline
\end{tabular}

\footnotetext{
${ }^{1}$ For simplicity, only the best-fit equations of multiple regression (backward elimination) that improved further the relationship obtained from linear or polynomial regressions are shown.

${ }^{2} \mathrm{peNDF}_{>1.18}=$ Physically effective NDF measured as the NDF content of TMR multiplied by amount of $\mathrm{DM}_{>1.18-\mathrm{mm}}$ (Mertens, 1997); FDOM = amount of digestible OM of forages in TMR estimated by MAFF (1990); $\mathrm{FNDF}=$ forage NDF; NFC = nonfiber carbohydrate calculated by difference $100-(\% \mathrm{CP}+\% \mathrm{NDF}+\%$ fat $+\%$ ash); peNDF $_{>8}=$ physically effective NDF measured as the NDF content of TMR multiplied by amount of $\mathrm{DM}_{>8-\mathrm{mm}}$ (Lammers et al., 1996); RDSI = intake of ruminally degradable starch from grain.

${ }^{3}$ Root mean square error.

${ }^{4}$ Two models are shown because including FDOM and RDSI in the same model to predict ruminal $\mathrm{pH}$ induced model overparameterization.
}

$\mathrm{kg}$ of $\mathrm{DM}$ ) is an indicator particularly of the quality (ruminal degradability) of forage in TMR, whereas RDSI (kg/d) accounts for daily intake of ruminally degradable starch from grain. The positive relationship of FDOM to $\mathrm{pH}\left(\mathrm{R}^{2}=0.24\right)$ showed that FDOM affects the rumen conditions and should be considered when formulating TMR for dairy cows. Similarly, Allen (1997) reported a linear positive relationship $\left(\mathrm{R}^{2}=0.18\right)$ between ruminal $\mathrm{pH}$ and the amount of $\mathrm{OM}$ truly degraded in the rumen. Inclusion of FDOM along with peNDF $_{>1.18}$ in the model slightly increased the accuracy of estimation of ruminal $\mathrm{pH}$ from $\mathrm{R}^{2}=0.67$ to $\mathrm{R}^{2}=$ 0.72. The positive effect of FDOM on ruminal $\mathrm{pH}$ was probably a result of the positive effect of good-quality forage in promoting digesta stratification and turnover in the rumen and consequently stimulating forage intake and chewing activity (Tafaj et al., 2004b, 2005b). On the other hand, inclusion of RDSI in the model with peNDF $>1.18$ increased the accuracy of estimation of ruminal $\mathrm{pH}$ up to $75 \%$. Krause et al. (2002b) found that diets containing finer haylage particles and highmoisture corn reduced mean ruminal $\mathrm{pH}$ more than diets containing coarser haylage and dry ground corn. Furthermore, Beauchemin and Rode (1997) reported that rapidly digested starch sources, such as barley grain, increase the need for effective fiber. The results of the present study indicate that ruminal $\mathrm{pH}$ is influenced both by dietary components affecting chewing and salivary secretion, and by those affecting ruminal carbohydrate fermentation. Nevertheless, even though
FDOM and RDSI serve as an indication of forage quality and of the intake in ruminally degradable starch, respectively, we are aware that in vitro- and in situestimated FDOM and RDSI cannot completely represent the in vivo ruminal degradation of $\mathrm{OM}$ of the experimental TMR used in this study. More research with known in vivo FDOM and RDSI is needed to validate this assumption.

Kohn (2000) reported that ruminal $\mathrm{pH}$ is a function of digestion and absorption, changes in strong ion concentration, and changes in the partial pressure of $\mathrm{CO}_{2}$ in the rumen fluid. This study supports the theory that ruminal $\mathrm{pH}$ is an important parameter for determining physical effectiveness of dairy rations. However, the estimation proposed here should be adjusted for further details, such as rumen site and time of $\mathrm{pH}$ measurement, which in turn influences the $\mathrm{pH}$ readings. As described in Materials and Methods, there were differences among studies in measuring ruminal $\mathrm{pH}$ over time. Some studies measured $\mathrm{pH}$ from ruminal fluid from spot samples, whereas in others, ruminal $\mathrm{pH}$ was continuously measured. Although the measurements of ruminal $\mathrm{pH}$ covered at least a period until 8 to $10 \mathrm{~h}$ postfeeding and the analysis accounted for unequal variances among studies and for random effect of reporting results from studies with different laboratorial and experimental conditions, the methodological variability cannot be completely excluded. The $\mathrm{pH}$ values analyzed in this study tended more to characterize a daily mean $\mathrm{pH}$ measured in the ruminal fluid, and 
hence represents neither $\mathrm{pH}$ readings in the peak of fermentation nor ruminal solid-phase $\mathrm{pH}$. Nordlund and Garrett (1994) proposed sampling within 4 to $8 \mathrm{~h}$ postfeeding in TMR-fed herds to measure ruminal $\mathrm{pH}$ near the nadir. Furthermore, several researchers (Yang and Varga, 1989; Martin et al., 1999) recorded $\mathrm{pH}$ that was 0.2 to 0.4 units higher in the ventral rumen sac than in the dorsal rumen sac. In addition, Tafaj et al. (2005a) reported $\mathrm{pH}$ values 0.3 and 0.6 units higher in free rumen liquid than in the squeezed rumen liquid of solid digesta phase collected from the top and bottom of the rumen sac, respectively.

However, results of this study indicate that accounting for dietary physically effective fiber is a more efficient procedure to assess effective fiber adequacy of dairy cow ration than simply taking into account dietary NDF or FNDF. In this context, the PSPS constitutes a useful on-farm choice for frequent on-site examination of ration particle size and ration physical effectiveness, thus increasing the efficacy for controlling SARA on dairy farms. But, as this study demonstrates, not only physically effective fiber, but also the amount of digestible $\mathrm{OM}$ of forages and grain fermentability affects ruminal $\mathrm{pH}$, which are not accounted for when using PSPS to calculate peNDF.

Effects of dietary factors on ruminal $\mathrm{pH}$ were not completely consistent with the effects on ruminal VFA content or molar percentage of acetate, propionate, or butyrate, which were not affected to the same extent or were not affected at all compared with ruminal $\mathrm{pH}$ (Tables 4 and 6). The effects of dietary particle size on the production and absorption of VFA are often contradictory. Reducing dietary particle size might increase the ruminal degradation rate of fiber, but this does not inevitably lead to an increase of rumen OM degradability or the production of VFA, as particulate passage rate can also be increased (Soita et al., 2003). However, Allen (2000) stated that decreasing forage particle size might increase DMI, which could also increase the availability of ruminally digested $\mathrm{OM}$ and hence the production of VFA.

Total VFA was negatively affected by peNDF, whether expressed as peNDF $>8 \quad\left(R^{2}=0.25\right)$ or $\operatorname{peNDF}_{>1.18},\left(\mathrm{R}^{2}=0.12\right)$. This decrease of VFA in the rumen fluid with increasing dietary peNDF might be attributed to the positive effect of peNDF on rumen motility. Taylor and Allen (2005) stated that as ruminal motility increases, VFA molecules are expected to be replenished at the rumen wall more rapidly, increasing the concentration gradient across the ruminal epithelium and rate of VFA absorption. Increasing the dietary NFC:NDF ratio, NFC content, or RDSI from grain increased the ruminal VFA linearly, whereas acetate to propionate ratio and butyrate percentage decreased
(Tables 4 and 6). This is in accordance with the results found by Firkins et al. (2001), who reported that acetate to propionate ratio correlated positively to FNDF and negatively to nonstructural carbohydrates in the diet of dairy cows.

\section{Chewing Activity}

Total chewing time ranged from 425 to $969 \mathrm{~min} / \mathrm{d}$ $(691 \pm 11.2 \mathrm{~min} / \mathrm{d}$; mean $\pm \mathrm{SE})$, and rumination time ranged between 151 and $632 \mathrm{~min} / \mathrm{d}(434 \pm 8.29 \mathrm{~min} / \mathrm{d}$; mean $\pm \mathrm{SE}$ ). The mean value of rumination found here is consistent with that found by Beauchemin et al. (1994), who reported that high-producing dairy cows consuming large quantities of DM tended to ruminate more than $360 \mathrm{~min} / \mathrm{d}$ unless digestive upset occurs. This was equivalent to a ruminative minimum of $16 \mathrm{~min} / \mathrm{kg}$ of DM for $22 \mathrm{~kg} / \mathrm{d}$ of DMI. About 14\% of 99 treatment means used for rumination in this study did not achieve a rumination time of $360 \mathrm{~min} / \mathrm{d}$; and $25 \%$ of the reports gave values lower than $16 \mathrm{~min} / \mathrm{kg}$ of $\mathrm{DM}$ (data not shown). Although the mean DMI in this study was about $1.03 \mathrm{~kg} / \mathrm{d}$ higher than in that of Beauchemin et al. (1994), if we consider these criteria, it could be stated that these results do not represent a sufficient rumination activity. Table 2 gives an overview of the chewing indices. The range of time spent chewing and ruminating was high in this study; cows spent 17.9 to $47.1 \mathrm{~min}$ of chewing per $\mathrm{kg}$ of $\mathrm{DM}(30.1 \pm 0.59 \mathrm{~min} / \mathrm{kg}$ of $\mathrm{DM})$ and 54.3 to $160 \mathrm{~min} / \mathrm{kg}$ of NDF $(103 \pm 2.48 \mathrm{~min} / \mathrm{kg}$ of NDF), whereas chewing time spent per kilogram of peNDF $_{>1.18}$ was $167 \pm 9.67$ min. Sudweeks et al. (1981) proposed that chewing corrected for DMI as a criterion for physical effectiveness of forages. They further proposed values equal to or greater than $30 \mathrm{~min} / \mathrm{kg}$ of DM as suitable for limiting the risk of digestive disorders. Based on the recommendation of Sudweeks et al. (1981), $51 \%$ of 99 treatment means analyzed here were below this criterion, ranging from 17.9 to $29.9 \mathrm{~min} / \mathrm{kg}$ of $\mathrm{DM}$ (data not shown). De Brabander et al. (2002) suggested that dairy cows should achieve between 59 and $72.8 \mathrm{~min}$ of chewing time per $\mathrm{kg}$ of DM from forages to prevent ruminal disorders and milk fat depression. Only 2 treatment means out of 99 were below this criterion in this study (result not shown). Tafaj et al. (2005c) estimated that for dairy cows to achieve a chewing time of $74 \mathrm{~min} /$ $\mathrm{kg}$ of DM from a long-chopped hay, diets should contain at least $10.7 \%$ long-chopped hay-crude fiber, which in turn corresponded to $28 \% \mathrm{NDF}$ or $19 \%$ peNDF and $60 \%$ slowly degradable concentrate in the diet. Furthermore, Tafaj et al. (2005c) reported that rations should contain at least $10.0 \%$ long-chopped hay-crude fiber to maintain $3.4 \%$ milk fat, which is close to $10.7 \%$ long-chopped hay- 
Table 7. Equations ${ }^{1}$ for linear regression of response of chewing parameters to different dietary factors in dairy cows fed TMR

\begin{tabular}{|c|c|c|c|c|c|c|c|}
\hline \multirow{2}{*}{$\begin{array}{l}\text { Chewing parameters } \\
\text { (Y) }\end{array}$} & \multirow{2}{*}{$\begin{array}{l}\text { Dietary factor }{ }^{2} \\
\text { (X) }\end{array}$} & \multicolumn{4}{|c|}{ Parameter estimates } & \multicolumn{2}{|c|}{ Model statistics } \\
\hline & & Intercept & $\mathrm{SE}_{\text {Intercept }}$ & Slope & $\mathrm{SE}_{\text {Slope }}$ & $\mathrm{RMSE}^{3}$ & $\mathrm{R}^{2}$ \\
\hline \multirow{5}{*}{$\begin{array}{l}\text { Total chewing time, } \\
\mathrm{min} / \mathrm{d}\end{array}$} & $\operatorname{peNDF}_{>1.18}, \%$ & 563 & 27.9 & 5.86 & 1.26 & 85.1 & 0.17 \\
\hline & peNDFI $_{>8}, \%$ & 627 & 19.6 & 6.46 & 1.71 & 92.3 & 0.13 \\
\hline & FNDF, $\%$ & 521 & 27.0 & 7.75 & 1.23 & 74.1 & 0.23 \\
\hline & FDOM, $\mathrm{g} / \mathrm{kg}$ of $\mathrm{DM}$ & 521 & 27.2 & 0.54 & 0.09 & 72.6 & 0.23 \\
\hline & NFC, $\%$ & 495 & 62.9 & 4.94 & 1.67 & 95.3 & 0.10 \\
\hline \multirow{4}{*}{$\begin{array}{l}\text { Rumination time, } \\
\mathrm{min} / \mathrm{d}\end{array}$} & peNDF $_{>1.18}, \%$ & 317 & 20.9 & 5.38 & 0.94 & 63.7 & 0.24 \\
\hline & $\mathrm{peNDF}_{>8}, \%$ & 365 & 11.8 & 6.25 & 0.92 & 61.1 & 0.27 \\
\hline & FNDF, $\%$ & 312 & 20.1 & 5.39 & 0.91 & 54.9 & 0.21 \\
\hline & $\mathrm{FDOM}, \mathrm{g} / \mathrm{kg}$ of DM & 288 & 19.2 & 0.45 & 0.06 & 51.3 & 0.29 \\
\hline
\end{tabular}

\footnotetext{
${ }^{1}$ Only significant relationships are shown $(P<0.05)$.

${ }^{2}$ peNDFI $_{>8}=$ Physically effective NDF measured as the NDF content of TMR multiplied by amount of $\mathrm{DM}_{>8 \text {-mm }}$ (Lammers et al., 1996); peNDF ${ }_{>1.18}=$ physically effective NDF measured as the NDF content of TMR multiplied by amount of $\mathrm{DM}_{>1.18-\mathrm{mm}}$ (Mertens, 1997); FNDF = forage NDF; FDOM = amount of digestible OM of forages in TMR estimated by MAFF (1990); NFC = nonfiber carbohydrate calculated by difference $100-(\% \mathrm{CP}+\% \mathrm{NDF}+\%$ ether extract $+\%$ crude ash $)$

${ }^{3} \mathrm{RMSE}=$ Root mean square error.
}

crude fiber needed to achieve a chewing time of $74 \mathrm{~min} /$ $\mathrm{kg}$ DM from long-chopped hay.

In Table 7, the significant linear relationships between dietary factors and chewing parameters are given, and in Table 8, the results of the analysis of multiple regression using backward elimination procedure are summarized. Total chewing and rumination time are positively affected by peNDF, FNDF, and FDOM contents of the ration, albeit to a lower extent than on ruminal $\mathrm{pH}$. Total chewing activity was positively affected by dietary NFC, presumably because of the positive effect of dietary NFC on DMI. These results agree with those of Firkins et al. (2001), who reported that increasing dietary FNDF and nonstructural carbohydrate concentrations linearly increased chewing activity ( $\mathrm{min} / \mathrm{kg}$ of NDF). Similarly, Beauchemin and Yang (2005) reported a linearly increased chewing time from 702 to $783 \mathrm{~min} / \mathrm{d}$, and rumination time from 441 to $494 \mathrm{~min} / \mathrm{d}$ with increasing $\mathrm{peNDF}_{>8}$ in the diet from 8.9 to $11.5 \%$. Based on this finding, Beauchemin and Yang (2005) postulated that a level of $\mathrm{peNDF}_{>8}$ above $10 \%$ in the dairy cow diet is required to avoid reduction of chewing activity.

Figure 2 shows the relationship between time spent chewing per kilogram of peNDF $>1.18$ intake and the concentration of peNDF $>1.18$ in TMR. Cows spent less time chewing per unit of peNDF $>1.18$ when the percentage of dietary $\mathrm{peNDF}_{>1.18}$ was increased. The chewing index $(\mathrm{min} / \mathrm{kg}$ of peNDF $>1.18)$ was quadratically reduced when the percentage of peNDF $>1.18$ in TMR was increased. This finding is in agreement with Beauchemin and Yang (2005), who reported a linearly increased chewing index from 326 to $378 \mathrm{~min} / \mathrm{kg}$ of $\mathrm{peNDF}_{>8}$ with decreasing dietary peNDF ${ }_{>8}$ from 11.5 to $8.9 \%$ of ration DM. Similarly, Tafaj et al. (2005c) reported a linearly increased time spent chewing from 99.4 to $134.8 \mathrm{~min} / \mathrm{kg}$

Table 8. Best-fit equations for multiple regression ${ }^{1}$ of chewing parameters to different dietary factors in dairy cows

\begin{tabular}{|c|c|c|c|c|c|c|c|}
\hline \multirow{2}{*}{$\begin{array}{l}\text { Chewing parameters } \\
\text { (Y) }\end{array}$} & \multirow{2}{*}{$\begin{array}{l}\text { Dietary factor }{ }^{2} \\
\text { (X) }\end{array}$} & \multicolumn{4}{|c|}{ Parameter estimates } & \multicolumn{2}{|c|}{ Model statistics } \\
\hline & & Intercept & $\mathrm{SE}_{\text {Intercept }}$ & Slope & $\mathrm{SE}_{\text {Slope }}$ & $\mathrm{RMSE}^{3}$ & $\mathrm{R}^{2}$ \\
\hline \multirow{3}{*}{$\begin{array}{l}\text { Total chewing time, } \\
\mathrm{min} / \mathrm{d}\end{array}$} & $\operatorname{peNDF}_{>1.18}, \%$ & 165 & 68.0 & 6.51 & 1.40 & 76.4 & 0.44 \\
\hline & FDOM, g/kg of DM & & & 6.69 & 1.36 & & \\
\hline & NFC, $\%$ & & & 0.39 & 0.11 & & \\
\hline \multirow{2}{*}{$\begin{array}{l}\text { Rumination time, } \\
\mathrm{min} / \mathrm{d}\end{array}$} & peNDF $_{>1.18}, \%$ & 231 & 28.4 & 5.14 & 1.08 & 59.7 & 0.36 \\
\hline & $\mathrm{FDOM}, \mathrm{g} / \mathrm{kg}$ of $\mathrm{DM}$ & & & 0.33 & 0.08 & & \\
\hline
\end{tabular}

${ }^{1}$ For simplicity, only the best-fit equations of multiple regression (backward elimination) that improved further the relationship obtained from linear regressions are shown.

${ }^{2} \mathrm{peNDF}_{>1.18}=$ Physically effective NDF measured as the NDF content of TMR multiplied by amount of $\mathrm{DM}_{>1.18-\mathrm{mm}}$ (Mertens, 1997); FDOM = amount of digestible OM of forages in TMR estimated by MAFF (1990); $\mathrm{NFC}=$ nonfiber carbohydrate calculated by difference $100-(\% \mathrm{CP}+\% \mathrm{NDF}+\%$ ether extract $+\%$ crude ash).

${ }^{3} \mathrm{RMSE}=$ Root mean square error 


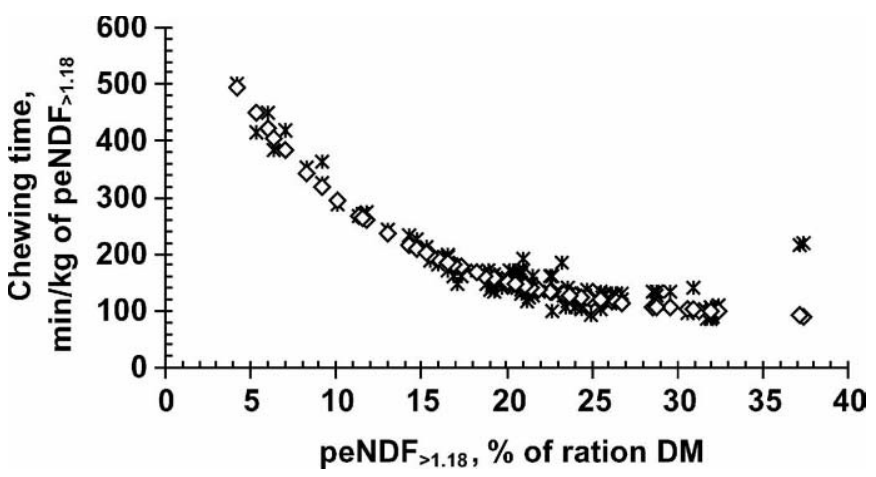

Figure 2. Relationship of physically effective NDF $\left(\mathrm{peNDF}_{>1.18}\right)$ to observed chewing index adjusted for the random experiment effect and unequal variance. The best-fit, quadratic regression chewing time $=628.8( \pm 13.8)-38.8( \pm 1.35) \mathrm{peNDF}_{>1.18}+0.73( \pm 0.03) \mathrm{peNDF}^{2}$ 1.18 ; root mean square error $=24.82 ; \mathrm{R}^{2}=0.91 ;$ Asymptotic function $(\diamond)$ chewing time $=80.4+664 \mathrm{e}^{(-0.94 \mathrm{peNDF}>1.18)}$ using Proc NLIN (SAS Institute, 2001). To achieve $150 \mathrm{~min} / \mathrm{kg}$ of $\mathrm{peNDF}_{>1.18}$ the ration should contain about $20 \%$ peNDF $_{>1.18}$.

of peNDF as dietary peNDF reduced from 39 to $19 \%$ of ration DM. These results suggest that dietary peNDF may affect chewing activity either through prolonging chewing time or decreasing chewing index. Mertens (1997) suggested that dairy cow diets should contain $22.3 \%$ peNDF to assure a chewing activity of $150 \mathrm{~min} /$ $\mathrm{kg}$ of peNDF to maintain optimal ruminal function. As shown in Figure 2, TMR should contain $\sim 20 \%$ peNDF $>$ 1.18 to achieve $150 \mathrm{~min} / \mathrm{kg}$ of peNDF $>1.18$, which is again somewhat lower than the peNDF percentage recommended by Mertens (1997).

Among the systems proposed to estimate the minimum amount of fiber necessary in rations for lactating dairy cows, most have attempted to guide ration formulation by predicting the amount of chewing that various feedstuffs would generate, or their relative effectiveness at maintaining milk fat percentage (Mertens, 2000). Mertens (1997) suggested that for cows to maintain $3.6 \%$ milk fat, they should achieve a chewing time of $744 \mathrm{~min} / \mathrm{d}$ or $36.1 \mathrm{~min} / \mathrm{kg}$ of DM. The chewing time needed to maintain a specified milk fat percentage from cows in early lactation fed TMR is shown in Table 9. Cows needed a chewing time of $797 \mathrm{~min} / \mathrm{d}$ or $36.5 \mathrm{~min} /$ $\mathrm{kg}$ of DM to maintain 3.6\% milk fat. Chewing index $(\mathrm{min} / \mathrm{kg}$ of $\mathrm{DM})$ corresponded better than total chewing time to the estimation of Mertens (1997).

\section{Fiber Digestibility}

Digestibilities of NDF and ADF were linearly increased as dietary peNDF and NDF were increased, whereas NDF digestibility decreased linearly with increasing NFC concentration and NFC:NDF ratio in the diet (Table 10). Increasing peNDF $>1.18$ in TMR by $1 \%$ increased NDF digestibility about $0.41 \%\left(\mathrm{R}^{2}=0.56\right)$. Increasing peNDF in TMR positively affected chewing activity and especially ruminal $\mathrm{pH}$, thus probably increasing saliva secretion that prevents ruminal $\mathrm{pH}$ from declining especially during meal consumption, as concluded by Beauchemin (2000) and Beauchemin and Yang (2005). Increased salivation during eating could enable the cow to buffer the large quantity of fermentation acids produced soon after the feed is consumed, whereas an increase in saliva output during rumination allows rumen buffering for a longer period after ingestion (Allen, 1997).

It is also believed that peNDF is the portion of a diet that stimulates chewing activity and ruminal digesta stratification (Mertens, 1997) and enhances mat consistency in the reticulorumen (Zebeli et al., 2005). On the other hand, increasing the consistency of ruminal mat improved fiber digestibility (Bal et al., 2000; Harvatine et al., 2002), through an increased selective retention ("filter bed" effect) of ruminal mat for undigested small feed particles (Sutherland, 1988). Furthermore, Tafaj et al. (1999, 2001) found that feeding dairy cows a ground- $(2.9 \mathrm{~mm})$ vs. a long- $(28.7 \mathrm{~mm})$ or a chopped$(9.2 \mathrm{~mm})$ hay impaired rumen conditions and reduced total mean retention time of digesta by $10 \mathrm{~h}$, which in turn led to a significant reduction of fiber digestibility of about $14 \%$ in dairy cows. Results of the present study show that depression of rumen $\mathrm{pH}$ due to reduction of peNDF in the diets likely contributes to the reduction of fiber digestibility, supporting the hypothesis that ruminal $\mathrm{pH}$ promotes cellulolytic activity. Ruminal cellulolytic activity is compromised when ruminal $\mathrm{pH}$ drops below 6.0 based on in vitro studies (Mouriño et al., 2001). Dietary peNDF, expressed as peNDF $>1.18$, appears to be a reliable predictor of fiber digestion. Because the amount of fiber that can be digested in the large intestine is limited, Yang and Beauchemin (2005) concluded that influence of dietary peNDF on digestibility is more pronounced for fiber than for starch, in which low ruminal digestion can be compensated for by high intestinal digestion. According to the equation given in Table 10, an NDF digestibility of $46.2 \%$ would be observed for a percentage of $\sim 19$ of dietary peNDF $>1.18$ (to maintain a rumen $\mathrm{pH}$ of 6.0 ), which corresponds with the mean NDF digestibility reported in this study $(46.9 \pm 0.96 \%$; Table 2$)$.

\section{Milk Production and Composition}

In this study, cows produced between 23.1 and 49.3 $\mathrm{kg}$ of milk/d and were between 9 and $170 \mathrm{~d}$ in milk (84.8 \pm 3.54 DIM; Table 2). All articles included in this study gave information about milk production and its composition. This is probably because milk parameters 
Table 9. Estimating the chewing time $(\mathrm{min} / \mathrm{d})$ and $(\mathrm{min} / \mathrm{kg}$ of $\mathrm{DM})$ required to maintain milk fat percentages of cows in early lactation

\begin{tabular}{lll}
\hline & \multicolumn{2}{c}{$\begin{array}{c}\text { Milk fat percentage regressed } \\
\text { on chewing time }\end{array}$} \\
\cline { 2 - 3 } & $\mathrm{min} / 24 \mathrm{~h}$ & $\mathrm{~min} / \mathrm{kg}$ of $\mathrm{DM}$ \\
\hline Linear regression & & \\
Mean milk fat intercept of all experiments & $2.16(0.13)^{1}$ & $2.50(0.11)$ \\
Linear regression coefficient & $0.0018(0.0002)$ & $0.030(0.0037)$ \\
Root mean square error (RMSE) & 0.188 & 0.41 \\
$\mathrm{R}^{2}$ & 0.50 & 36.5 \\
Requirement for specified milk fat percentage & & 30.0 \\
$3.6 \%$ milk fat & 797 & 23.3 \\
$3.4 \%$ milk fat & 687 & \\
$3.2 \%$ milk fat & 577 & \\
\hline
\end{tabular}

${ }^{1}$ Numbers in parentheses are standard error of estimates.

are easy to record, but as observed in this study, they did not satisfactorily respond to dietary factors considered.

Table 11 shows the results of linear regression of response of milk parameters to different dietary factors (only significant relationships are shown). The analysis of backward elimination of multiple regression did not further improve the relationship obtained from linear regression, and therefore no results are shown here. Milk yield was negatively affected by dietary NDF and FNDF and positively by NFC:NDF ratio, presumably because of their effect on DMI and energy concentration of the diet. Firkins et al. (2001) reported a negative correlation between milk yield and FNDF. Milk protein was not significantly affected by dietary factors studied here. However, the milk fat:protein ratio increased linearly with increasing peNDF ${ }_{>1.18}, \mathrm{FNDF}$, and FDOM in the diet. Milk fat percentage increased linearly with increasing dietary FNDF and FDOM. Firkins et al. (2001) reported that milk fat content responded in a quadratic fashion to dietary FNDF.
Beauchemin et al. (1994) and Mertens (1997) concluded that effects of particle size on milk fat content were likely to be observed when NDF levels were lower than the minimum recommended requirement. The NRC (2001) recommends a minimum of $25 \%$ dietary NDF and 19\% FNDF for dairy cows. However, in 16 cases (12\% of treatment means), both NDF and FNDF content in TMR were below the NRC (2001) recommendations (data not shown) in this study.

Failure to observe effects of dietary peNDF on milk yield and fat percentage contrasts with the effect of increasing dietary peNDF ${ }_{>1.18}$ on increasing ruminal $\mathrm{pH}$ and fiber digestibility. It is apparent that milk parameters are less sensitive to the effects of dietary peNDF than are other variables, such as ruminal $\mathrm{pH}$, chewing activity, and fiber digestibility. It is well recognized, however, that cows are in negative energy balance in early lactation; thus, animals must mobilize fat (NRC, 2001) and consequently, milk fat content artificially increases. On the other hand, milk fat is a variable that is closely related to dietary fat and the genetic

Table 10. Equations ${ }^{1}$ for linear regression of response of fiber digestibility to different dietary factors in dairy cows fed TMR

\begin{tabular}{|c|c|c|c|c|c|c|c|}
\hline \multirow{2}{*}{$\begin{array}{l}\text { Parameter } \\
\text { (Y) }\end{array}$} & \multirow{2}{*}{$\begin{array}{l}\text { Dietary factor }{ }^{2} \\
\text { (X) }\end{array}$} & \multicolumn{4}{|c|}{ Parameter estimates } & \multicolumn{2}{|c|}{ Model statistics } \\
\hline & & Intercept & $\mathrm{SE}_{\text {Intercept }}$ & Slope & $\mathrm{SE}_{\text {Slope }}$ & $\mathrm{RMSE}^{3}$ & $\mathrm{R}^{2}$ \\
\hline \multirow[t]{5}{*}{ NDF digestibility, \% } & peNDF $_{>1.18}, \%$ & 38.6 & 0.82 & 0.41 & 0.04 & 2.15 & 0.56 \\
\hline & $\mathrm{peNDF}_{>8}, \%$ & 43.3 & 0.63 & 0.36 & 0.05 & 2.96 & 0.30 \\
\hline & NDF, $\%$ & 31.4 & 1.83 & 0.51 & 0.06 & 2.88 & 0.42 \\
\hline & NFC, \% & 54.1 & 1.96 & -0.19 & 0.05 & 2.97 & 0.14 \\
\hline & NFC:NDF & 58.8 & 1.64 & -10.2 & 1.29 & 5.38 & 0.37 \\
\hline \multirow[t]{3}{*}{ ADF digestibility, $\%$} & peNDF $_{>1.18}, \%$ & 34.2 & 1.08 & 0.51 & 0.05 & 3.30 & 0.51 \\
\hline & peNDF $_{>8}, \%$ & 38.8 & 1.00 & 0.47 & 0.08 & 5.20 & 0.23 \\
\hline & NDF, $\%$ & 30.3 & 2.07 & 0.42 & 0.07 & 4.40 & 0.24 \\
\hline
\end{tabular}

\footnotetext{
${ }^{1}$ Only significant relationships are shown $(P<0.05)$.

${ }^{2} \mathrm{peNDF}_{>1.18}=$ Physically effective NDF measured as the NDF content of TMR multiplied by amount of $\mathrm{DM}_{>1.18-\mathrm{mm}}$ (Mertens, 1997); peNDFI $>$ $=$ physically effective NDF measured as the NDF content of TMR multiplied by amount of $\mathrm{DM}_{>8-\mathrm{mm}}$ (Lammers et al., 1996); $\mathrm{NFC}=$ nonfiber carbohydrate calculated by difference $100-(\% \mathrm{CP}+\% \mathrm{NDF}+\%$ ether extract $+\%$ crude ash $)$.

${ }^{3} \mathrm{RMSE}=$ Root mean square error.
} 
Table 11. Equations ${ }^{1}$ for linear regression of response of milk parameters to different dietary factors in dairy cows fed TMR

\begin{tabular}{|c|c|c|c|c|c|c|c|}
\hline \multirow{2}{*}{$\begin{array}{l}\text { Milk parameter } \\
\text { (Y) }\end{array}$} & \multirow{2}{*}{$\begin{array}{l}\text { Dietary factor }{ }^{2} \\
\text { (X) }\end{array}$} & \multicolumn{4}{|c|}{ Parameter estimates } & \multicolumn{2}{|c|}{ Model statistics } \\
\hline & & Intercept & $\mathrm{SE}_{\text {Intercept }}$ & Slope & $\mathrm{SE}_{\text {Slope }}$ & $\mathrm{RMSE}^{3}$ & $\mathrm{R}^{2}$ \\
\hline \multirow[t]{3}{*}{ Milk yield, kg } & $\mathrm{NDF}, \%$ & 46.9 & 2.44 & -0.389 & 0.077 & 5.19 & 0.16 \\
\hline & NFC:NDF & 19.7 & 3.23 & 21.851 & 4.715 & 5.27 & 0.18 \\
\hline & NFC:NDF ${ }^{2}$ & & & -6.652 & 1.660 & & \\
\hline \multirow[t]{2}{*}{ Milk fat, $\%$} & $\mathrm{peNDF}_{>1.18}, \mathrm{~kg}$ & 2.76 & 0.19 & 0.212 & 0.072 & 0.34 & 0.11 \\
\hline & peNDF $^{2}>1.18, \mathrm{~kg}$ & & & -0.014 & 0.006 & & \\
\hline \multirow[t]{3}{*}{ Fat-to-protein ratio in milk } & $\operatorname{peNDF}_{>1.18}, \%$ & 0.91 & 0.04 & 0.008 & 0.001 & 0.11 & 0.17 \\
\hline & FNDF, $\%$ & 0.90 & 0.04 & 0.008 & 0.001 & 0.11 & 0.14 \\
\hline & FDOM, $\mathrm{g} / \mathrm{kg}$ of DM & 0.80 & 0.04 & 0.0009 & 0.0001 & 0.10 & 0.32 \\
\hline
\end{tabular}

\footnotetext{
${ }^{1}$ Only significant relationships are shown $(P<0.05)$.

${ }^{2} \mathrm{FNDF}=$ Forage NDF; NFC $=$ nonfiber carbohydrate calculated by difference $100-(\% \mathrm{CP}+\% \mathrm{NDF}+\%$ fat $+\%$ ash $) ;$ peNDF $>1.18=$ physically effective NDF measured as the NDF content of TMR multiplied by amount of DM $\mathrm{DM}_{>1.18-\mathrm{mm}}$ (Mertens, 1997); FDOM = amount of digestible OM of forages in TMR estimated by MAFF (1990).

${ }^{3}$ RMSE $=$ Root mean square error.
}

merit of the animal. Mertens (1997) concluded that ruminal $\mathrm{pH}$ may be a better indication of ruminal health and optimal function than the maintenance of milk fat production in this stage of lactation for dairy cows.

\section{Systems for Estimation of Physically Effective Fiber and Response Variables}

For physical evaluation of forages or TMR, different wet and dry sieving techniques have been proposed. Murphy and Zhu (1997) compared 9 methods (3 dry and 6 wet) for evaluating particle size distribution of feedstuffs. Based on median particle size estimates (central tendency), they concluded that 6 of those (including all dry sieving techniques tested) had relatively consistent estimates of particle size distribution. Lammers et al. (1996) developed the simplified method for evaluating particle size distribution of forages and TMR using PSPS. The PSPS is based on the properties of Standard S424 of the American Society of Agricultural Engineers (ASAE, 1998) and has been proven to generate similar results to the vertical oscillating sieving method (Lammers et al., 1996; Buckmaster, 2000; Teimouri Yansari et al., 2004). The PSPS device contains 2 sieves and a bottom pan. Using the PSPS, particle distribution is determined by separating particles according to size; $>19 \mathrm{~mm}$, between 19 and $8 \mathrm{~mm}$, and $<8$ mm (Lammers et al., 1996).

The new version of PSPS (Kononoff et al., 2003b) is constructed from 3 sieves with pores measuring 19, 8 , and $1.18 \mathrm{~mm}$ and a solid bottom pan, permitting the estimation of peNDF $>1.18$ according to Mertens (1997). Teimouri Yansari et al. (2004) estimated peNDF $>1.18$ of forages (alfalfa and corn silage) and TMR using both a vertical oscillating sieve and the new PSPS and re- ported very similar results. The PSPS is a quick, costeffective method, and produces consistent results in measuring particle size distribution of forages and TMR. These properties made the PSPS method a valuable on-farm choice to estimate forage and TMR particle size distribution around the world.

As shown in Table 2, the amount of physically effective NDF in TMR was higher when estimated as peNDF $_{>1.18}$ than when estimated as peNDF $>8$. This is because peNDF ${ }_{>1.18}$ contains a large pool of particles retained on the lower screens (i.e., particles greater than $1.18 \mathrm{~mm}$ and smaller than $8 \mathrm{~mm}$ ). Research results (Kononoff and Heinrichs, 2003a; Kononoff et al., 2003a; Plaizier, 2004) showed that the proportion of this pool could range from 30 to $50 \%$ in the TMR. Beauchemin et al. (2003) reported a 50\% higher peNDF of TMR when it was estimated as peNDF $>1.18$ compared with peNDF $>8$, because peNDF ${ }_{>8}$ does not consider particles $<8 \mathrm{~mm}$ or steam-rolled concentrate, whereas peNDF $_{>1.18}$, does.

Results of this study showed that differences in the quantity of peNDF $>8$ and peNDF $>1.18$ were reflected by their effects on the response variables studied. Thus, regarding the chewing activity, the peNDF ${ }_{>8}$ affected rumination time to a slightly higher extent than did peNDF $_{>1.18}\left(R^{2}=0.27\right.$ vs. $\left.R^{2}=0.24\right)$, whereas total chewing time was more accurately estimated when peNDF was expressed as peNDF $>1.18\left(R^{2}=0.17\right.$ vs. $\left.R^{2}=0.13\right)$. On the other hand, the accuracy of estimation for ruminal $\mathrm{pH}$ and NDF digestibility was higher when peNDF was expressed as peNDF $>1.18$. Although the content of peNDF $_{>8}$ is lower than peNDF $>1.18$ in the TMR, the effectiveness of peNDF $>8$ to stimulate rumination is higher. Buckmaster (2000) proposed an effective fiber index that weights NDF content by particle size. To calculate 
the effective fiber index of a ration, NDF content of each fraction of particles retained on each sieve is multiplied by a relative effectiveness coefficient, which is different for every particle fraction retained on the screens of PSPS. Based on these relative effectiveness coefficients, Buckmaster (2000) stated that particles $>19 \mathrm{~mm}$ are twice as effective for stimulating rumination and contributing to a rumen mat as those between 8 and 19 $\mathrm{mm}$, whereas particles $<8 \mathrm{~mm}$ have one-fifth of the effectiveness of particles between 8 and $19 \mathrm{~mm}$. This contrasts with the peNDF $>1.18$ method of Mertens (1997), which equally weights particle mass $>1.18 \mathrm{~mm}$ in stimulating chewing activity and neglects the rest. Krause et al. (2002b) corrected the particle size distribution of TMR by that of orts and found a good relationship only between chewing and rumination activity with DMI from particles retained on the $19-\mathrm{mm}$ screen of PSPS ( $r=0.61$ each), but not with DMI from particles retained on the 8-mm screen or the pan. Furthermore, Krause et al. (2002b) found no relationship between ruminal $\mathrm{pH}$ and DMI from particles retained on the 19and 8-mm screens of PSPS.

Results of ruminal $\mathrm{pH}$ and NDF digestibility in the present study did not support dietary peNDF measured as the proportion of particles retained on $8 \mathrm{~mm}$ sieve as the best indicator to express the physical effectiveness of TMR, even though peNDF $>8$ slightly better estimated rumination time. Indeed, the relationship between chewing and rumination time and ruminal $\mathrm{pH}$ was low in this study $(r=0.25$ and $r=0.33$, respectively; results not shown). Cassida and Stokes (1986) estimated saliva flow rates of 150,177 , and $300 \mathrm{~mL} / \mathrm{min}$ during resting, eating, and ruminating, respectively. Using these estimated flow rates, the contribution in saliva production in the present study would be 112 , 46 , and $130 \mathrm{~L} / \mathrm{d}$ for resting, eating, and ruminating time, respectively (data calculated based on chewing times given in Table 2). It could be stated that decreased saliva flow associated with a decreased rumination time could be partly balanced by saliva secretion during resting time. Krause et al. (2002b) reported that salivary buffering is only one of many factors determining ruminal $\mathrm{pH}$.

Discrepancies between $\mathrm{peNDF}_{>8}$ and $\mathrm{peNDF}_{>1.18}$ to estimate rumination time, ruminal $\mathrm{pH}$, and fiber digestibility observed in this study indicate that these concepts cannot be used interchangeably. Although the peNDF $>8$ concept represents particles retained on the 8-mm sieve, which are expected to provoke an intensive saliva output, peNDF $>8$ was not the best parameter to estimate ruminal $\mathrm{pH}$ and fiber digestibility.

It is believed that diets with less than 7\% long particles (particles retained on the top screen of the separator) put cows at increased risk of SARA, particularly if these diets are also borderline or low in chemical fiber content (Grant et al., 1990a). However, increasing chemical fiber content may compensate for short particle length (Beauchemin et al., 1994). On the other hand, diets having excessive long forage particles can paradoxically increase the risk of SARA, especially when long particles are unpalatable and sortable (K. M. Krause and G. R. Oetzel, unpublished data). Several researchers (Calberry et al., 2003; Leonardi and Armentano, 2003; Beauchemin and Yang, 2005) reported different particle size distributions for TMR and orts for cows fed TMR ad libitum, indicating selective consumption. By feeding Holstein cows a corn silage-based TMR, we found (Junck et al., 2004) that across treatments (4 different theoretical particle lengths, 5.5, 8.1, 11, and $14 \mathrm{~mm}$ ), difference between the offered TMR and orts were $26 \%$ for particles retained on the $8-\mathrm{mm}$ screen (i.e., sum of particles retained on 19- and 8-mm sieves of PSPS). This difference was only $9 \%$ for particles retained on the 1.18-mm screen (i.e., sum of particles retained on 19-, 8-, and 1.18-mm sieves of PSPS) (in both cases were more long particles in orts than in the offered TMR). This indicates that if we evaluate our TMR only based on particles retained on the 8-mm screen (i.e., peNDF $>8$ ), our estimation to evaluate effective fiber content of the truly consumed TMR was biased $26 \%$ compared with only $9 \%$ bias if we estimated the peNDF of TMR based on particles retained on the 1.18$\mathrm{mm}$ screen (i.e., peNDF ${ }_{>1.18}$ ). This was because cows sorted against coarse particles of TMR and preferred to consume short particles and crushed corn kernels, which are more palatable and digestible. However, this sorting against the coarse particles was more evident for TMR containing the longest levels of corn silage (11 and $14 \mathrm{~mm}$ ) compared with TMR containing the shortest levels ( 8.1 and $5.5 \mathrm{~mm}$ ), which showed a lower sorting rate. It seems, therefore, that an advantage of estimating peNDF of the ration based on particles retained on 1.18-mm screen consists in this, that this system, better reflects the TMR really consumed by dairy cows and can reduce the estimation bias related to sorting consumption. Under practical conditions on dairy farms, the evaluation of particle size distribution is mainly carried out in TMR and not in orts. For this reason, the evaluation of the ration based only on the pool of long particles of the original TMR does not appear to be an adequate approach for estimation of physical effectiveness in dairy cows fed TMR ad libitum.

\section{CONCLUSIONS}

This study showed that the concentration and intake of peNDF $>1.18$ should be considered in formulation of TMR for high-yielding dairy cows. Results of this data 
analysis showed that peNDF $>1.18$ provided a satisfactory estimation of mean ruminal $\mathrm{pH}$ and fiber digestibility. Indeed, the peNDF $>1.18$ approach explained $67 \%$ of the variation in ruminal $\mathrm{pH}$. On the other hand, peNDF $_{>1.18}$, was poorly, although positively, correlated to daily chewing $\left(R^{2}=0.17\right)$ and rumination $\left(R^{2}=0.24\right)$ activity. Results from this analysis showed that milk parameters are less sensitive to the effects of dietary peNDF than are other variables, such as ruminal $\mathrm{pH}$, fiber digestibility, and chewing activity.

Using the peNDF $>1.18$ approach, the requirements for physically effective fiber in high-yielding dairy cows fed TMR in an ad libitum intake were estimated to be about $19 \%$ of ration DM $(4.1 \mathrm{~kg} / \mathrm{d}$ or $0.6 \mathrm{~kg} / 100 \mathrm{~kg}$ of BW) to maintain a ruminal $\mathrm{pH}$ of about 6.0. Inclusion of FDOM and RDSI from grain in the model together with peNDF $_{>1.18}$ appeared to be advantageous in improving the accuracy of estimation. This approach appeared to complement the concept of peNDF that does not account for differences in ruminal fermentability of feeds. Moreover, this study showed that the intake of rapidly fermentable carbohydrates is more important than total NFC percentage of the diet to be taken into account in terms of avoiding SARA in high-yielding dairy cows.

When peNDF was measured as the proportion of particles retained on an 8-mm PSPS screen $\left(\mathrm{peNDF}_{>8}\right)$, ruminal $\mathrm{pH}$ responded in a quadratic fashion but the confidence of estimation was lower $\left(R^{2}=0.27\right)$ compared with peNDF $_{>1.18}$. Furthermore, measuring physically effective NDF as peNDF $>1.18$ might be more realistic in terms of expression of effective fiber in the TMR truly consumed by dairy cows.

Results of this study indicated that accounting for dietary physically effective fiber is a more efficient procedure to assess effective fiber adequacy of dairy cow rations than simply taking into account dietary NDF or FNDF. In this context, the PSPS constitutes a useful on-farm choice for frequent on-site examination of ration particle size and ration physical effectiveness.

\section{REFERENCES}

Allen, M. S. 1995. Fiber requirements: Finding an optimum can be confusing. Feedstuffs 67:13-16.

Allen, M. S. 1997. Relationship between fermentation acid production in the rumen and the requirement for physically effective fiber. J. Dairy Sci. 80:1447-1462.

Allen, M. S. 2000. Effect of diet on short-term regulation of feed intake by lactating dairy cattle. J. Dairy Sci. 83:1598-1624.

Allen, D. M., and R. J. Grant. 2000. Interactions between forage and wet corn gluten feed as sources of fiber in diets for lactating dairy cows. J. Dairy Sci. 83:322-331.

ASAE. 1998. S424: Method of determining and expressing particle size of chopped forage materials by sieving. ASAE Standards. Am. Soc. Agric. Eng., St. Joseph, MI.

Bal, M. A., R. D. Shaver, A. G. Jirovec, K. J. Shinners, and J. G. Coors. 2000. Crop processing and chop length of corn silage: Effects on intake, digestion, and milk production by dairy cows. J. Dairy Sci. 83:1264-1273.

Beauchemin, K. A. 2000. Managing rumen fermentation in barley based diets: Balance between high production and acidosis. Adv. Dairy Technol. 12:109-125.

Beauchemin, K. A., B. I. Farr, L. M. Rode, and G. B. Schaalje. 1994. Effects of alfalfa chop length and supplementary long hay on chewing and milk production of dairy cows. J. Dairy Sci. 77:1326-1339.

Beauchemin, K. A., and L. M. Rode. 1997. Minimum versus optimum concentrations of fiber in dairy cow diets based on barley silage and concentrates of barley or corn. J. Dairy Sci. 80:1629-1639.

Beauchemin, K. A., L. M. Rode, and M. V. Eliason. 1997. Chewing activities and milk production of dairy cows fed alfalfa as hay, silage, or dried cubes of hay or silage. J. Dairy Sci. 80:324-333.

Beauchemin, K. A., and W. Z. Yang. 2005. Effects of physically effective fiber on intake, chewing activity, and ruminal acidosis for dairy cows fed diets based on corn silage. J. Dairy Sci. 88:2117-2129.

Beauchemin, K. A., W. Z. Yang, and L. M. Rode. 2003. Effects of particle size of alfalfa based-dairy cow diets on chewing activity, ruminal fermentation, and milk production. J. Dairy Sci. 86:630-643.

Boddugari, K., R. J. Grant, R. Stock, and M. Lewis. 2001. Maximal replacement of forage and concentrate with a new wet corn milling product for lactating dairy cows. J. Dairy Sci. 84:873-884.

Buckmaster, D. M. 2000. Particle size in dairy cows. Pages 109-128 in Recent advances in animal nutrition. P. C. Garnsworthy and J. Wiseman, ed. Nottingham University Press, Nottingham, UK.

Calberry, J. M., J. C. Plaizier, M. S. Einarson, and B. W. McBridge. 2003. Effects of replacing chopped alfalfa hay with alfalfa silage in a total mixed ration on production and rumen conditions of lactating dairy cows. J. Dairy Sci. 86:3611-3619.

Cassida, K. A., and M. R. Stokes. 1986. Eating and resting salivation in early lactating dairy cows. J. Dairy Sci. 69:1282-1292.

Clark, P. W., and L. E. Armentano. 1997. Influence of particle size on the effectiveness of beet pulp fiber. J. Dairy Sci. 80:898-904.

Clark, P. W., and L. E. Armentano. 1999. Influence of particle size on the effectiveness of the fiber in corn silage. J. Dairy Sci. 82:581-588.

Clark, P. W., and L. E. Armentano. 2002. Influence of particle size on the effectiveness of the fiber in alfalfa silage. J. Dairy Sci. 85:3000-3007.

De Brabander, D. L., J. L. De Boever, J. M. Vanacker, and N. E. Geerts. 2002. Evaluation and effects of physical structure in dairy cattle nutrition. Pages 182-197 in Recent developments and perspectives in bovine medicine, Proc. XXII World Buiatrics Congr., Hanover, Germany. M. Kaske, H. Scholz, and M. Höltershinken, ed. Tierärtzliche Hochschule, Hanover, Germany.

Einarson, M. S., J. C. Plaizier, and K. M. Wittenberg. 2004. Effects of barley silage chop length on productivity and rumen conditions of lactating dairy cows fed total mixed ration. J. Dairy Sci. 87:2987-2996.

Eun, J.-S., K. A. Beauchemin, S.-H. Hong, and W. Z. Yang. 2004. Effects of mechanical processing on the nutritive value of barley silage for lactating dairy cows. J. Dairy Sci. 87:4170-4177.

Fernandez, I., C. Martin, M. Champion, and B. Michalet-Doreau. 2004. Effect of corn hybrid and chop length of whole-plant corn silage on digestion and intake by dairy cows. J. Dairy Sci. 87:1298-1309.

Firkins, J. L., M. L. Eastridge, N. R. St-Pierre, and S. M. Noftsger. 2001. Effects of grain variability and processing on starch utilization by lactating dairy cattle. J. Dairy Sci. 79(E. Suppl.):E218E238.

Garrett, E. F., M. N. Pereira, K. V. Nordlund, L. E. Armentano, W. J. Goodger, and G. R. Oetzel. 1999. Diagnostic methods for the detection of subacute ruminal acidosis in dairy cows. J. Dairy Sci. 82:1170-1178.

Grant, R. J., V. F. Colenbrander, and D. R. Mertens. 1990a. Milk fat depression in dairy cows: Role of particle size of alfalfa hay. J. Dairy Sci. 73:1823-1833. 
Grant, R. J., V. F. Colenbrander, and D. R. Mertens. 1990b. Milk fat depression in dairy cows: Role of silage particle size. J. Dairy Sci. 73:1834-1842.

Harvatine, D. I., J. E. Winkler, M. Devant-Guille, J. L. Firkins, N. R. St-Pierre, B. S. Oldick, and M. L. Eastridge. 2002. Whole linted cottonseed as a forage substitute: Fiber effectiveness and digestion kinetics. J. Dairy Sci. 85:1988-1999.

Junck, B., M. Tafaj, Q. Zebeli, R. Funk, H. Steingass, and W. Drochner. 2004. Einfluss der Häcksellänge auf Strukturwert und Qualität der Maissilage (Influence of length of the cut on the physical evaluation and quality of corn silage). Page 96 in Proc. 116th VDLUFA Congress, Rostock, Germany. (Abstr.) VDLUFAVerlag, Darmstadt, Germany.

Kohn, R. A. 2000. Three conditions of the ruminal milieu that determine pH. Proc. 25th Conf. Rumen Function, Chicago, IL. Department of Animal Science, Michigan State University, East Lansing. Online. Available http://www.msu.edu/user/rumen/index.htm

Kononoff, P. J., and A. J. Heinrichs. 2003a. The effect of corn silage particle size and cottonseed hulls on cows in early lactation. J. Dairy Sci. 86:2438-2451.

Kononoff, P. J., and A. J. Heinrichs. 2003b. The effect of reducing alfalfa haylage particle size on cows in early lactation. J. Dairy Sci. 86:1445-1457.

Kononoff, P. J., A. J. Heinrichs, and D. A. Buckmaster. 2003b. Modification of the Penn State forage and total mixed ration particle separator and the effects of moisture content on its measurements. J. Dairy Sci. 86:1858-1863.

Kononoff, P. J., A. J. Heinrichs, and H. A. Lehman. 2003a. The effect of corn silage particle size on eating behavior, chewing activities, and rumen fermentation in lactating dairy cows. J. Dairy Sci. 86:3343-3353.

Krause, K. M., and D. K. Combs. 2003. Effects of forage particle size, forage source, and grain fermentability on performance and ruminal pH in midlactation cows. J. Dairy Sci. 86:1382-1397.

Krause, K. M., D. K. Combs, and K. A. Beauchemin. 2002a. Effects of forage particle size and grain fermentability in midlactation dairy cows. I. Milk production and diet digestibility. J. Dairy Sci. 85:1936-1946.

Krause, K. M., D. K. Combs, and K. A. Beauchemin. 2002b. Effects of forage particle size and grain fermentability in midlactation dairy cows. II. Ruminal $\mathrm{pH}$ and chewing activity. J. Dairy Sci. 85:1947-1957.

Lammers, B. P., D. R. Buckmaster, and A. J. Heinrichs. 1996. A simple method for the analysis of particle sizes of forage and total mixed rations. J. Dairy Sci. 79:922-928.

Le Liboux, S., and J. L. Peyrand. 1998. Effect of forage particle size and intake level on fermentation patterns and sites and extent of digestion in dairy cows fed mixed diets. Anim. Feed Sci. Technol. 73:131-150.

Le Liboux, S., and J. L. Peyrand. 1999. Effect of forage particle size and feeding frequency on fermentation patterns and sites and extent of digestion in dairy cows fed mixed diets. Anim. Feed Sci. Technol. 76:297-319.

Leonardi, C., and L. E. Armentano. 2003. Effect of quantity, quality and length of alfalfa hay on selective consumption by dairy cows. J. Dairy Sci. 86:557-564.

Leonardi, C., K. J. Shinners, and L. E. Armentano. 2005. Effect of different dietary geometric mean length particle length and particle size distribution of oat silage on feeding behavior and productive performance of dairy cattle. J. Dairy Sci. 88:698-710.

MAFF. 1990. UK Tables of nutritive value and chemical composition of feedingstuffs. Standard Committee on Tables of Feed Composition, Ministry of Agriculture, Fisheries and Food. Rowett Research Services, Aberdeen, UK.

Martin, C., E. Devillard, and B. Michalet-Doreau. 1999. Influence of sampling site on concentrations and carbohydrate-degrading enzyme activities of protozoa and bacteria in the rumen. J. Anim. Sci. 77:979-987.

Mertens, D. R. 1997. Creating a system for meeting the fiber requirements of dairy cows. J. Dairy Sci. 80:1463-1481.
Mertens, D. R. 2000. Physically effective NDF and its use in dairy rations explored. Feedstuffs April 10: 11-14.

Mouriño, F., R. Akkarawongosa, and P. J. Weimer. 2001. Initial pH as a determinant of cellulose digestion rate by mixed ruminal microorganisms in vitro. J. Dairy Sci. 84:848-859.

Murphy, M. R., and J. S. Zhu. 1997. A comparison of methods to analyze particle size as applied to alfalfa haylage, corn silage, and concentrate mix. J. Dairy Sci. 80:2932-2938.

National Research Council. 2001. Nutrient Requirements of Dairy Cattle. 7th Rev. ed. Natl. Acad. Sci., Washington, DC.

Nordlund, K. V., and E. F. Garrett. 1994. Rumenocentesis: A technique for collecting rumen fluid for the diagnosis of subacute rumen acidosis in dairy herds. Bovine Pract. 28:109-112.

Oba, M., and M. S. Allen. 2000a. Effects of brown midrib 3 mutation in corn silage on productivity of dairy cows fed two concentrations of dietary neutral detergent fiber: 1 . Feeding behavior and nutrient utilization. J. Dairy Sci. 83:1333-1341.

Oba, M., and M. S. Allen. 2000b. Effects of brown midrib 3 mutation in corn silage on productivity of dairy cows fed two concentrations of dietary neutral detergent fiber: 2. Chewing activity. J. Dairy Sci. 83:1342-1349.

Oba, M., and M. S. Allen. 2000c. Effects of brown midrib 3 mutation in corn silage on productivity of dairy cows fed two concentrations of dietary neutral detergent fiber: 3 . Digestibility and microbial efficiency. J. Dairy Sci. 83:1350-1358.

Offner, A., A. Bach, and D. Sauvant. 2003. Quantitative review of in situ starch degradation in the rumen. Anim. Feed Sci. Technol. 106:81-93

Oldick, B. S., J. L. Firkins, and N. R. St-Pierre. 1999. Estimation of microbial nitrogen flow to the duodenum of cattle based on dry matter intake and diet composition. J. Dairy Sci. 82:1497-1511.

Onetti, S. G., R. D. Shaver, S. J. Bertics, and R. R. Grummer. 2003 Influence of corn silage particle length on the performance of lactating dairy cows fed supplemental tallow. J. Dairy Sci. 86:2949-2957.

Owens, F. N., D. S. Secrist, W. J. Hill, and D. R. Gill. 1998. Acidosis in cattle: A review. J. Anim. Sci. 76:275-286.

Pitt, R. E., J. S. Van Kessel, D. G. Fox, A. N. Pell, M. C. Barry, and P. J. Van Soest. 1996. Prediction of ruminal volatile fatty acids and $\mathrm{pH}$ within the net carbohydrate and protein system. J. Anim. Sci. 74:226-244.

Plaizier, J. C. 2004. Replacing chopped alfalfa hay with alfalfa silage in barley grain and alfalfa based total mixed rations for lactating dairy cows. J. Dairy Sci. 87:2495-2505.

San Emeterio, F., R. B. Reis, W. E. Campos, and L. D. Satter. 2000. Effect of coarse or fine grinding on utilization of dry or ensiled corn by lactating dairy cows. J. Dairy Sci. 83:2839-2848.

SAS Institute. 2001. SAS User's Guide. Statistic, Version 8.2 ed. SAS Inst., Inc., Cary, NC.

Sauvant, D., J. M. Perez, and G. Tran. 2004. Tables of composition and nutritional value of feed materials: Pigs, poultry, cattle, sheep, goats, rabbits, horses, fish. Wageningen Academic Publishers, Wageningen, The Netherlands.

Schwab, E. C., R. D. Shaver, K. J. Shinners, J. G. Lauer, and J. G. Coors. 2002. Processing and chop length in brown midrib corn silage on intake, digestion, and milk production by dairy cows. J. Dairy Sci. 85:613-623.

Soita, H. W., D. A. Christensen, and J. J. McKinnon. 2000. Influence of particle size on the effectiveness of the fiber in barley silage. J. Dairy Sci. 83:2295-2300.

Soita, H. W., D. A. Christensen, and J. J. McKinnon. 2003. Effects of barley silage particle size and concentrate level on rumen kinetic parameters and fermentation parameters in steers. Can. J. Anim. Sci. 83:533-539.

Stone, W. C. 2004. Nutritional approaches to minimize subacute ruminal acidosis and laminitis in dairy cattle. J. Dairy Sci. 87(E. Suppl.):E12-E26.

St-Pierre, N. R. 2001. Integrating quantitative finding from multiple studies using mixed model methodology. J. Dairy Sci. 84:741-755.

Sudweeks, E. M., L. O. Ely, D. R. Mertens, and L. R. Sisk. 1981. Assessing minimum amounts and form of roughages in ruminant diets: Roughage value index system. J. Anim. Sci. 53:1406-1415. 
Sutherland, T. M. 1988. Particle separation in the forestomachs of sheep. Pages 43-73 in Aspects of digestive physiology in ruminants. A. Dobson and M. J. Dobson, ed. Cornell Univ. Press. Ithaca, NY.

Tafaj, M., B. Junck, A. Maulbetsch, H. Steingass, H.-P. Piepho, and W. Drochner. 2004b. Digesta characteristics of dorsal, middle and ventral rumen of cows fed with different hay qualities and concentrates levels. Arch. Anim. Nutr. 58:325-342.

Tafaj, M., V. Kolaneci, B. Junck, A. Maulbetsch, H. Steingass, and W. Drochner. 2005b. Influence of fiber content and concentrate level on chewing activity, ruminal digestion, digesta passage rate and nutrient digestibility in dairy cows in late lactation. AsianAust. J. Anim. Sci. 18:1116-1124.

Tafaj, M., A. Maulbetsch, Q. Zebeli, H. Steingass, and W. Drochner. 2005c. Effects of physically effective fiber concentration of diets consisting of hay and slowly degradable concentrate on chewing activity in mid lactation dairy cows under constant intake level. Arch. Anim. Nutr. 59:313-324.

Tafaj, M., H. Steingass, A. Susenbeth, G. U. Lang, and W. Drochner. 1999. Influence of hay particle size at different concentrate and feeding levels on digestive processes and feed intake in ruminants. 1. Chewing activity and ruminal fermentation. Arch. Anim. Nutr. 52:167-184.

Tafaj, M., H. Steingass, and W. Drochner. 2001. Influence of hay particle size at different concentrate and feeding levels on digestive processes and feed intake in ruminants. 2. Passage, digestibility and feed intake. Arch. Anim. Nutr. 54:243-259.

Tafaj, M., Q. Zebeli, B. Junck, and W. Drochner. 2004a. Influence of particle size of grass silage fed as TMR on chewing activity and rumen fermentation in high-yielding dairy cows. Proc. Soc. Nutr. Physiol. 13:76. (Abstr.)
Tafaj, M., Q. Zebeli, B. Junck, H. Steingass, and W. Drochner. 2005a. Effects of particle size of a total mixed ration on in vivo ruminal fermentation patterns and inocula characteristics used for in vitro gas production. Anim. Feed Sci. Technol. 123-124:139-154.

Taylor, C. C., and M. S. Allen. 2005. Corn grain endosperm type and brown midrib 3 corn silage: Ruminal fermentation and $\mathrm{N}$ partitioning in lactating cows. J. Dairy Sci. 88:1434-1442.

Teimouri Yansari, A., R. Valizadeh, A. Naserian, D. A. Christensen, P. Yu, and F. Eftekhari Shahroodi. 2004. Effects of alfalfa particle size and specific gravity on chewing activity, digestibility, and performance of Holstein dairy cows. J. Dairy Sci. 87:3912-3924.

Yang, J. C., and G. A. Varga. 1989. Effect of sampling site on protozoa and fermentation end products in the rumen of dairy cows. J. Dairy Sci. 72:1492-1498.

Yang, W. Z., and K. A. Beauchemin. 2005. Effects of physically effective fiber on digestion and milk production by dairy cows fed diets based on corn silage. J. Dairy Sci. 88:1090-1098.

Yang, W. Z., K. A. Beauchemin, and L. M. Rode. 2001a. Effects of grain processing, forage to concentrate ratio, and forage particle size on rumen $\mathrm{pH}$ and digestion in dairy cows. J. Dairy Sci. 84:2203-2216.

Yang, W. Z., K. A. Beauchemin, and L. M. Rode. 2001b. Barley processing, forage:concentrate, and forage length effects on chewing and digesta passage in lactating cows. J. Dairy Sci. 84:2709-2720.

Yang, W. Z., K. A. Beauchemin, and L. M. Rode. 2002. Effects of particle size of alfalfa based-dairy cow diets on site and extent of digestion. J. Dairy Sci. 85:1958-1968.

Zebeli, Q., M. Tafaj, B. Junck, and W. Drochner. 2005. Effect of hay particle size and concentrate level on ruminal mat characteristics in dairy cows. Proc. Soc. Nutr. Physiol. 14:120. (Abstr.) 